\title{
Working
}

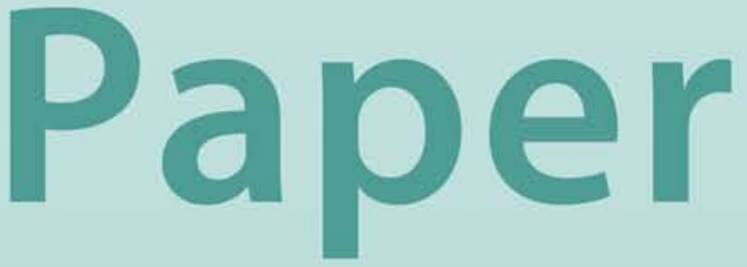




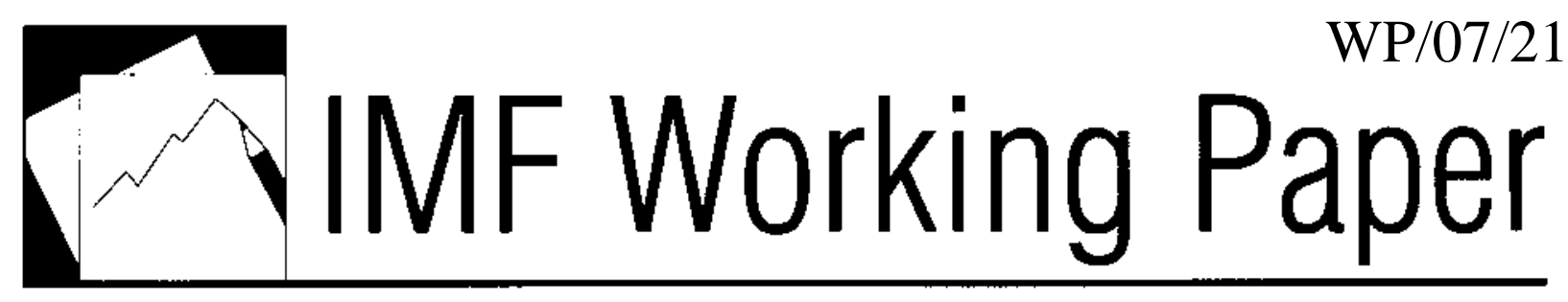

\section{Public Expenditure in Latin America: Trends and Key Policy Issues}

Benedict Clements, Christopher Faircloth, and Marijn Verhoeven 


\title{
IMF Working Paper
}

Western Hemisphere and Fiscal Affairs Departments

\section{Public Expenditure in Latin America: Trends and Key Policy Issues}

\section{Prepared by Benedict Clements, Christopher Faircloth, and Marijn Verhoeven ${ }^{1}$}

February 2007

\begin{abstract}
This Working Paper should not be reported as representing the views of the IMF. The views expressed in this Working Paper are those of the author(s) and do not necessarily represent those of the IMF or IMF policy. Working Papers describe research in progress by the author(s) and are published to elicit comments and to further debate.
\end{abstract}

This paper examines trends in government spending in Latin America from the mid-1990s to 2006. It also examines key policy issues, including the cyclicality of spending, public investment, public employment, and social expenditures. It finds that primary expenditures have trended upward for the past ten years as a share of GDP, driven by increases in current spending, in particular for social expenditures. Fluctuations in real spending have continued to follow a procyclical pattern. The paper finds that there is substantial scope to improve the efficiency of public investment, public employment, and social spending.

JEL Classification Numbers: E6, H5, O54

Keywords: Public Expenditure, Fiscal Policy, and Latin America

Author(s) E-Mail Address: bclements@imf.org; cfaircloth@imf.org; mverhoeven@imf.org

\footnotetext{
${ }^{1}$ The authors would like to acknowledge the useful comments received by Pablo Pereira, Roberto Steiner, and numerous colleagues in the IMF's Fiscal Affairs and Western Hemisphere Departments. Valuable research assistance was provided by Takahiro Atsuta, Priya Joshi, and Victoria Gunnarsson.
} 
Contents

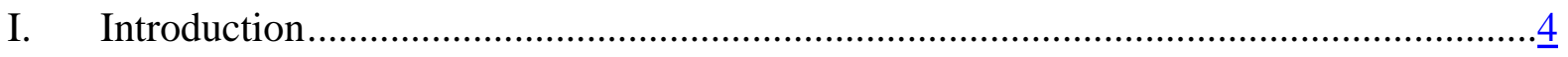

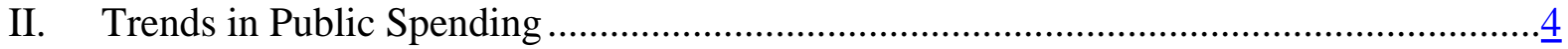

A. Overview of Aggregate Fiscal Trends .........................................................

B. Trends in Government Expenditure ...............................................................

III. Key Expenditure Policy Issues ...........................................................................11

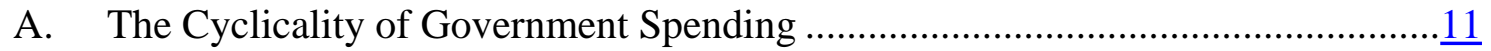

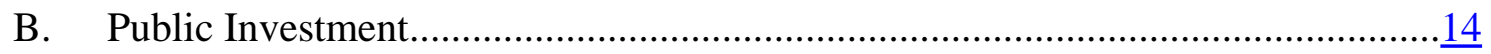

C. Public Sector Employment ….....................................................................17

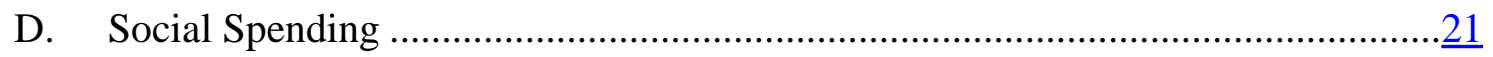

IV. Summary and Policy Implications …...............................................................

Appendices

I. Econometric Methodology Used to Assess the Cyclicality of Spending ......................26

II. The Efficiency of Public Investment in Latin America ............................................27

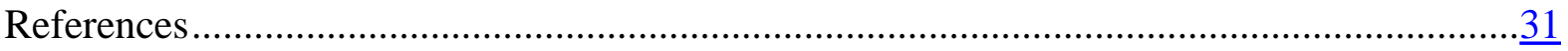

Tables

1. Estimates of the Short-Run Response of Spending to Output Shocks..........................12

2. Response of Expenditure to Output Gaps .............................................................13

3. Public Investment in Latin America and Other Regions, 1990-2006 ..........................15

4. General Government Wages and Salaries in Latin America and Other Regions, 2004 .......................................................................................... 17

5. Government Employment in Latin America and Other Regions, 1990s .......................18

6. Government Effectiveness in Latin America and Other Regions.................................18

7. General Government Social Spending in Latin America and Other

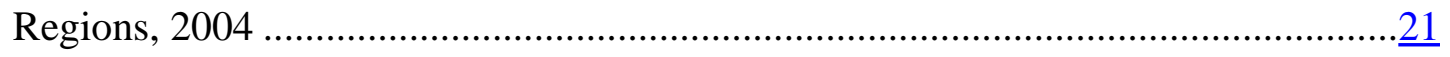

8. Distribution of Benefits from Social Spending to the Top and Bottom Quintiles..........24

Figures

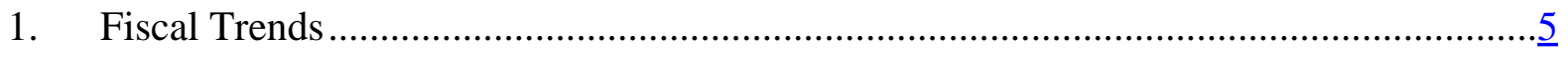

2. Primary Public Spending by Region...................................................................

3. Initial Primary Spending Levels (1995) and Increases (1995-2006) .............................

4. Real GDP, Revenues, and Primary Spending ........................................................

5. Public Sector Expenditures ..................................................................................

6. Average Public Sector Capital Spending .................................................................. 
7. Trends in Social Spending .......................................................................................10

8. Institutional and Infrastructural Performance-Deviation of Actual Indices from

Values Predicted by PPP-Adjusted Per Capita Income ................................................16

9. Public Share of Infrastructure Spending and Efficiency.................................................16

10. Relationship Between GDP Per Capita and Bureaucratic Quality ..................................19

11. The Quality of the Bureaucracy ..............................................................................

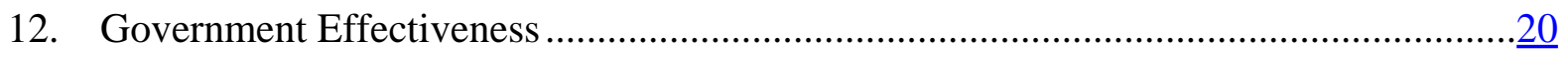




\section{INTRODUCTION}

The appropriate role of government spending in fostering economic growth remains an important element in the policy debate in Latin America. Beyond their macroeconomic impact, expenditure policies can affect growth through a number of channels, including their effects on the development of physical and human capital. ${ }^{2}$ These policies have an especially important role in Latin America, given the wide disparities in living standards among the rich and the poor in the region (de Ferranti and others, 2004). At the same time, public debt ratios_-notwithstanding recent reductions_-remain high at over 50 percent of GDP, limiting the ability of governments to meet social needs and bolster the region's infrastructure.

\section{This paper assesses trends in public expenditures in Latin America and discusses key} policy issues in the period ahead. The analysis covers 17 countries and trends in spending from the mid-1990s to 2006. ${ }^{3}$ In addition, the paper examines several key expenditure policy issues, including: (i) the cyclicality of government spending; (ii) public investment; (iii) public employment; and (iv) social expenditures.

\section{Trends in Public Spending}

\section{A. Overview of Aggregate Fiscal Trends}

Fiscal balances generally weakened in the latter half of the 1990s. Rising primary spending tended to outpace increases in revenues, contributing to a deterioration in primary balances of over 1 percentage point of GDP (Figure 1 ). ${ }^{4}$ Average primary balances fluctuated over a relatively narrow range over the period, although there were significant differences across countries. Revenue ratios rose in about half of the countries of the region, and on average increased by about a percentage point of GDP.

\footnotetext{
${ }^{2}$ For a more extensive overview of how fiscal policy and government expenditures affect growth, see Clements, Gupta, and Inchauste (2004).

${ }^{3}$ Countries comprise Argentina, Bolivia, Brazil, Chile, Colombia, Ecuador, Mexico, Peru, Paraguay, Uruguay, and Venezuela (South America and Mexico) and Costa Rica, El Salvador, Guatemala, Honduras, Nicaragua, and Panama (Central America). 2006 data refer to IMF staff projections as of end-August 2006.

${ }^{4}$ Figures based on the broadest definition of government available. For 14 of the 17 countries, expenditure data refer to the public sector or nonfinancial public sector (that is, general government, plus the capital expenditures of the public enterprises). For Argentina and Mexico, expenditures also include the current outlays of the public enterprises (e.g., wages), although in the case of the former these outlays are very small. For Chile, data cover general government; and for Guatemala, central government.
} 
Figure 1. Latin America: Fiscal Trends

(In percent of GDP) 1/

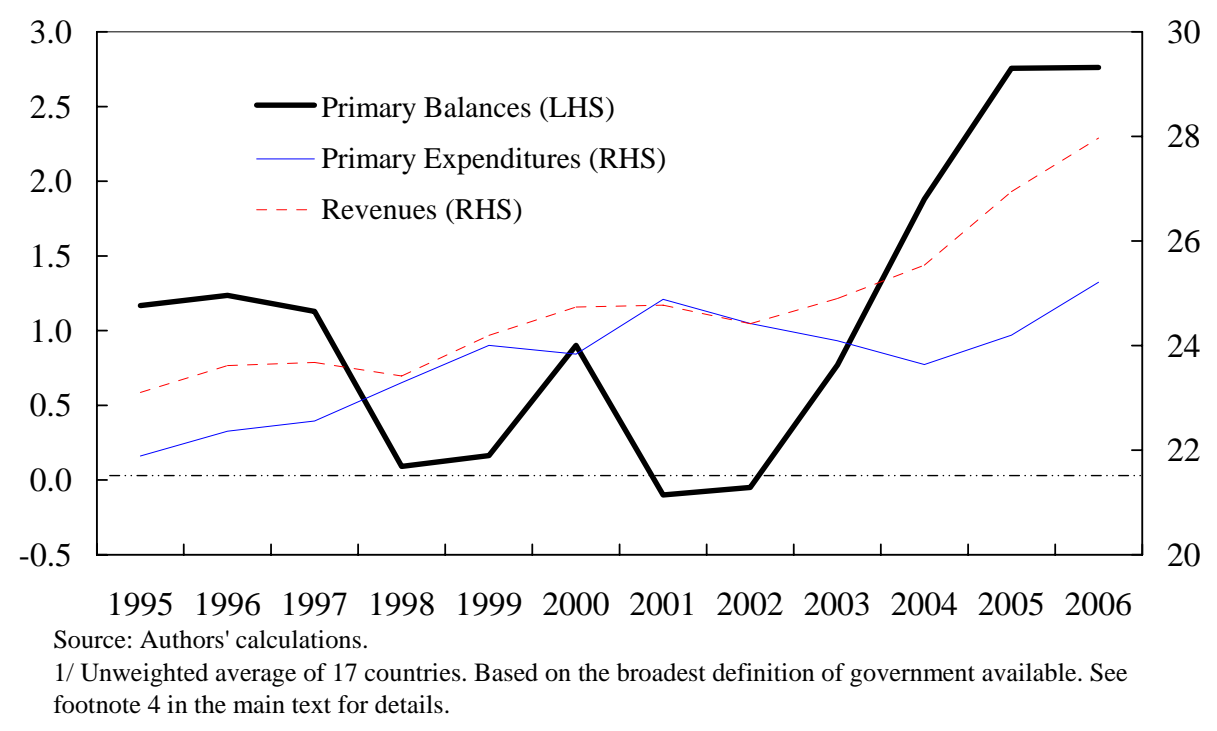

Fiscal positions have improved this decade, based largely on a strengthening of revenues. After a slight decline over 2000-02, average primary balances have trended upward, with primary surpluses in recent years exceeding substantially their mid-1990s levels. This owes largely to surging revenues, especially from commodities. Revenues have risen by an average of about 31/2 percentage points of GDP since 2002, with oil producers experiencing a boost in receipts of over 7 percent of GDP. ${ }^{5}$ Bolivia, Chile, and Peru have also benefited from the boom in metals prices and export-based revenues. Noncommodity revenues have also risen, on average, since 2002 in the 17 countries of the region-reflecting also improved tax administration-but by a more modest amount (about 1 percent of GDP) than commodity revenues. Higher primary surpluses, as well as other improvements in macroeconomic policies, have helped underpin the region's ongoing economic expansion. ${ }^{6}$

\section{Notwithstanding strengthened primary balances, public debt ratios remain above} desirable levels in many countries in the region. On a weighted average basis, public debt in Latin America is projected to remain above 50 percent of GDP by end-2006, little changed from the ratio prevailing in the mid-1990s. Given that the prudent maximum level of debt for a typical emerging market is generally much lower-according to some estimates, as low as 25 percent of GDP_-debt burdens remain a challenge to entrenching macroeconomic stability. ${ }^{7}$

\footnotetext{
${ }^{5}$ Oil producers comprise Ecuador, Mexico, and Venezuela.

${ }^{6}$ See IMF (2006b) for further discussion.

${ }^{7}$ See, for example, IMF (2003).
} 


\section{B. Trends in Government Expenditure}

\section{Trends across country groups and subperiods}

Primary outlays have drifted upward over time. In both Central America and South America and Mexico, primary spending has edged upward as a share of GDP since the mid1990s (Figure 2). The rise in outlays has not been continuous, however. During what could be called the "first phase" of spending increases (1995-2001), spending rose by 3 percentage points of GDP (the median increase was $1 \frac{1}{2}$ percent). Average spending ratios then experienced a period of decline during the economic downturn of 2002 and the first two years of the recent recovery (2003-04). The decline in spending was widespread, with 13 of the 17 countries trimming spending-to-GDP ratios between 2001 and 2004. More recently, there has been a "second phase" of spending increases with the maturation of the recovery, with outlays rising by about 11/2 percentage points of GDP between 2004 and 2006. With this second round of spending increases, outlays have now surpassed their previous peak ratio to GDP of 2001.

Figure 2. Latin America: Primary Public Spending by Region (In percent of GDP) 1/

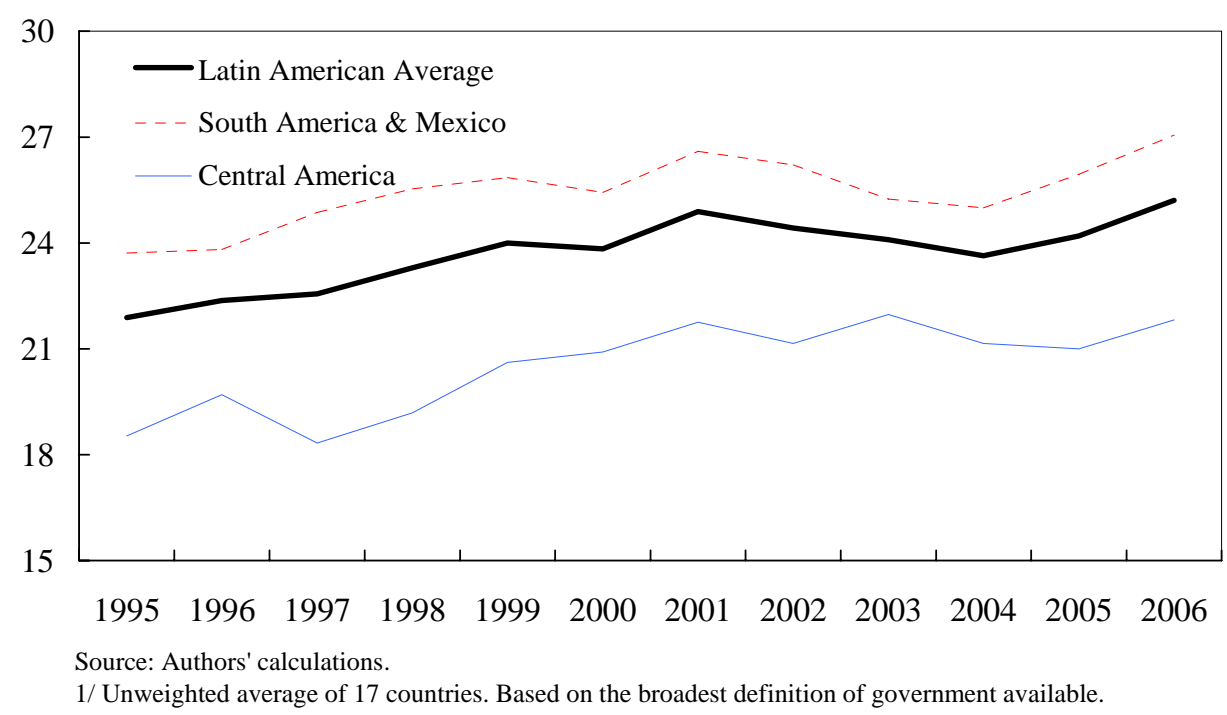

Spending increases were widespread across countries during the first phase (1995-2001). Outlays rose in all but 2 countries of the region-Paraguay and Peru-where spending was largely unchanged in relation to GDP. At the same time, there was a wide variance in spending increases across countries. In Brazil, spending rose by $81 / 2$ percentage points of GDP, driven by higher nonwage current outlays. In Honduras and Uruguay, outlays rose by over $5 \frac{1}{2}$ percent of GDP, with a large increase in the wage bill explaining much of the spending increase in the former. In Bolivia and Chile, spending also rose briskly (by about $4 \frac{1}{2}$ percent of GDP), owing to higher outlays for pensions (Bolivia) and higher social spending and capital expenditures (Chile). 
Spending increases were broad-based across the region in the second phase (2004-06). Expenditures climbed in all but 4 countries of the region. Spending hikes varied widely across countries, as reflected in the lower median increase in spending $\left(1 \frac{1}{2}\right.$ percentage point of GDP) than mean increase ( $1 \frac{1}{2}$ percent of GDP). The disparity reflected especially large increases in Venezuela (over 9 percent of GDP), as well as Bolivia, Brazil, and Nicaragua (all 21/2 percent of GDP or greater). On average, increases were notably lower in Central America (about $1 / 2$ percent of GDP), where countries have not benefited from the buoyant commodity revenues enjoyed by South America and Mexico.

\section{There has been no tendency for convergence in the size of government across the} region. In fact, countries with higher levels of initial spending in 1995 have experienced somewhat sharper increases in outlays (Figure 3). One notable exception is Uruguay, where fiscal adjustment in the wake of the crisis earlier this decade has left spending ratios below those prevailing in the mid-1990s.

Figure 3. Latin America: Initial Primary Spending Levels (1995) and

Increases (1995 - 2006)

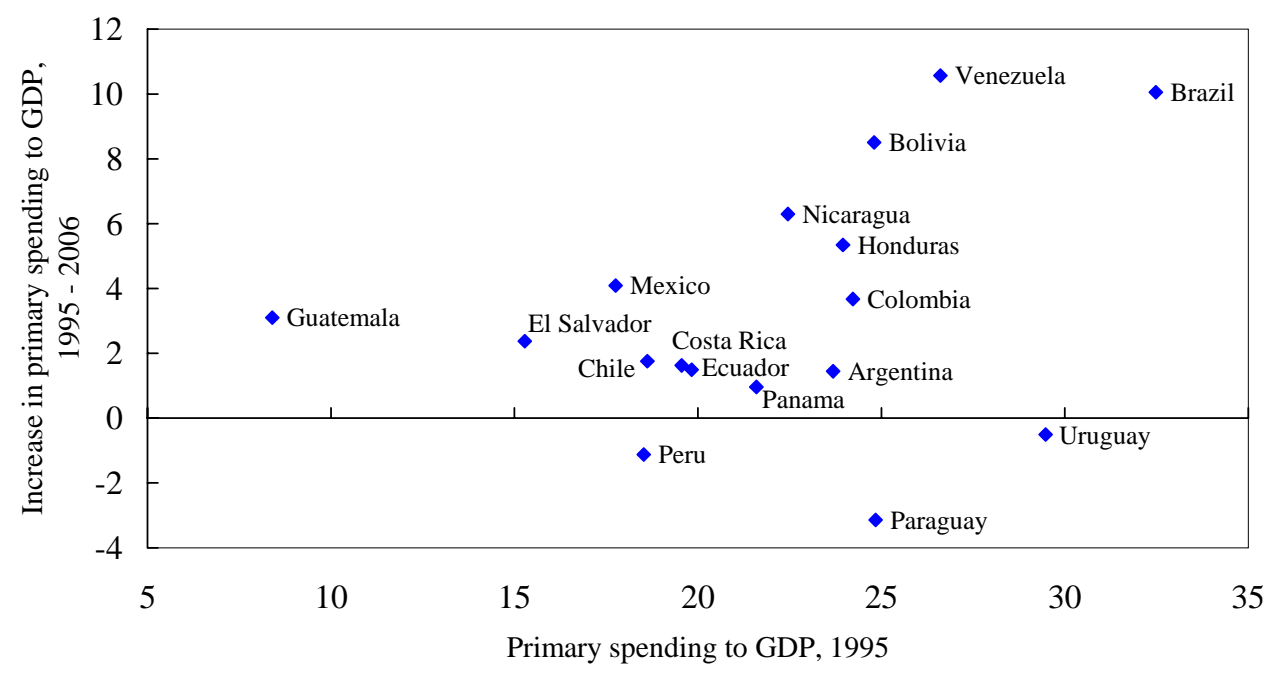

Source: Authors' calculations.

Budget rigidities have contributed to rising spending. In Brazil, for example, the revenuebased fiscal consolidation strategy in place since 1999, combined with extensive budget rigidities, has contributed to the large increase in spending since the mid-1990s. Revenue earmarking, in particular, led to spending increases as the revenue effort increased. Budget rigidities have also led to spending pressures in Colombia, especially during the late 1990s when both revenue and expenditure ratios rose. In Chile, in contrast, the relatively low level of budget rigidities, in tandem with its fiscal policy rule, have helped contain public spending increases in the face of rising revenues. ${ }^{8}$

\footnotetext{
${ }^{8}$ See Alier (2007) for a discussion of budget rigidities in Argentina, Brazil, Chile, and Ecuador.
} 
Relatively small overall changes in spending-to-GDP ratios mask the volatile and procyclical behavior of real expenditures. Real spending growth in the past decade has varied considerably from year to year, and has tended to follow the economic cycle and growth of real revenues (Figure 4). Real spending fell, for example, during the economic downturns in Argentina and Venezuela early in the decade, but since then has rebounded markedly. While real spending increases were well contained across the region during 200304 , they have accelerated over the past two years, with outlays climbing by an average of 8 percent per annum. ${ }^{9}$ Spending increases have been somewhat higher among commodity producers, but the expenditure boom has been a common phenomenon in the region, with governments in 15 of 17 countries increasing real outlays by 5 percent or more per annum in 2005-06.

Figure 4. Latin America: Real GDP, Revenues, and Primary Spending (Annual percent change) $1 /$

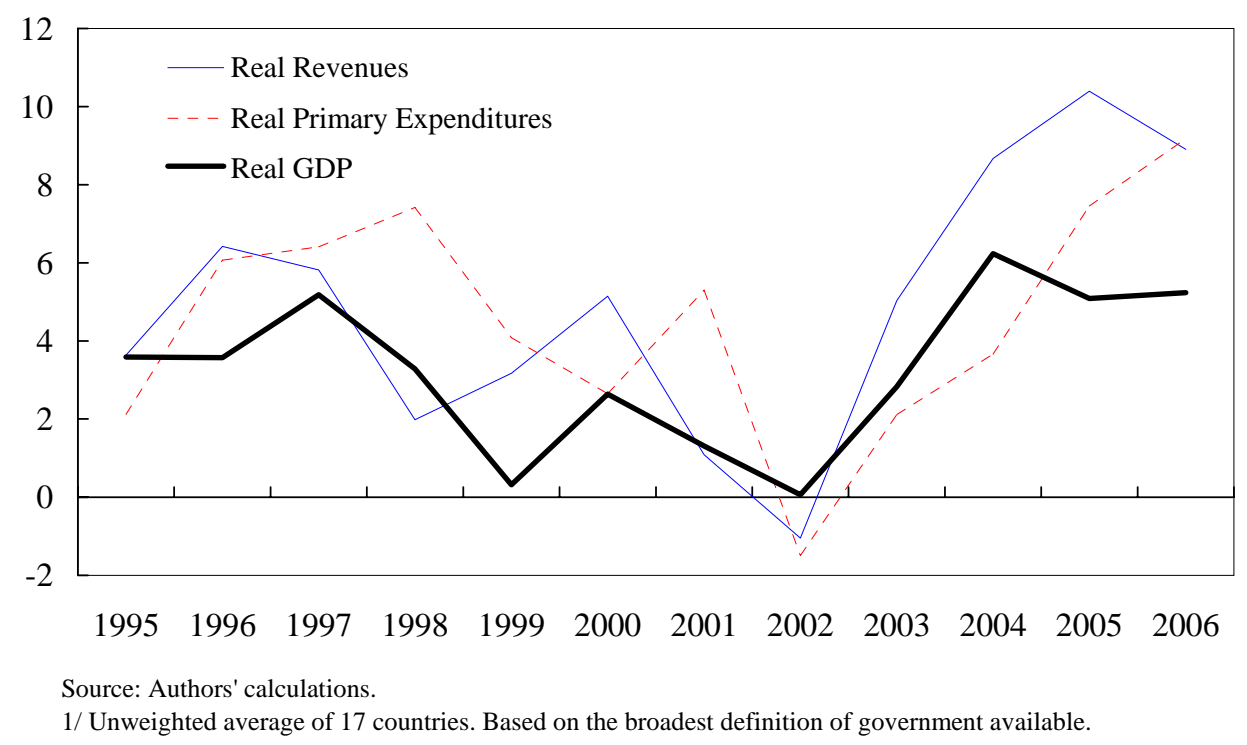

\section{Trends in spending categories}

The trend toward rising spending to GDP ratios over the past 10 years is attributable to higher primary current outlays (Figure 5). Wage bills have risen by about $1 / 2$ percentage point of GDP over this period — mostly in the late 1990s—while nonwage current outlays have increased by about 3 percentage points of GDP. As indicated below, rising social outlays appear to have accounted for this higher spending, including social insurance benefits.

Capital expenditures have tended to decline over time, although there has been a reversal of this trend of late. These outlays hovered near 6 percent of GDP in the latter half

\footnotetext{
${ }^{9}$ For a further assessment of recent trends in real spending growth by country, see IMF (2006b).
} 
of the 1990s, before falling nearly a percentage point of GDP through 2004. As a result, the share of capital spending in total primary expenditures has declined (Figure 6). In 2005, however, spending rose slightly, and in 2006, it is projected to have risen by close to $1 / 2$ percentage point to about 51/2 percent of GDP. Notwithstanding these increases, the ratio of capital expenditures falls short of the level reached at the end of the previous decade and, in light of rising current outlays, the share of spending allocated to public investment is projected to remain below that prevailing a decade ago.

Figure 5. Latin America: Public Sector Expenditures

(In percent of GDP) 1/

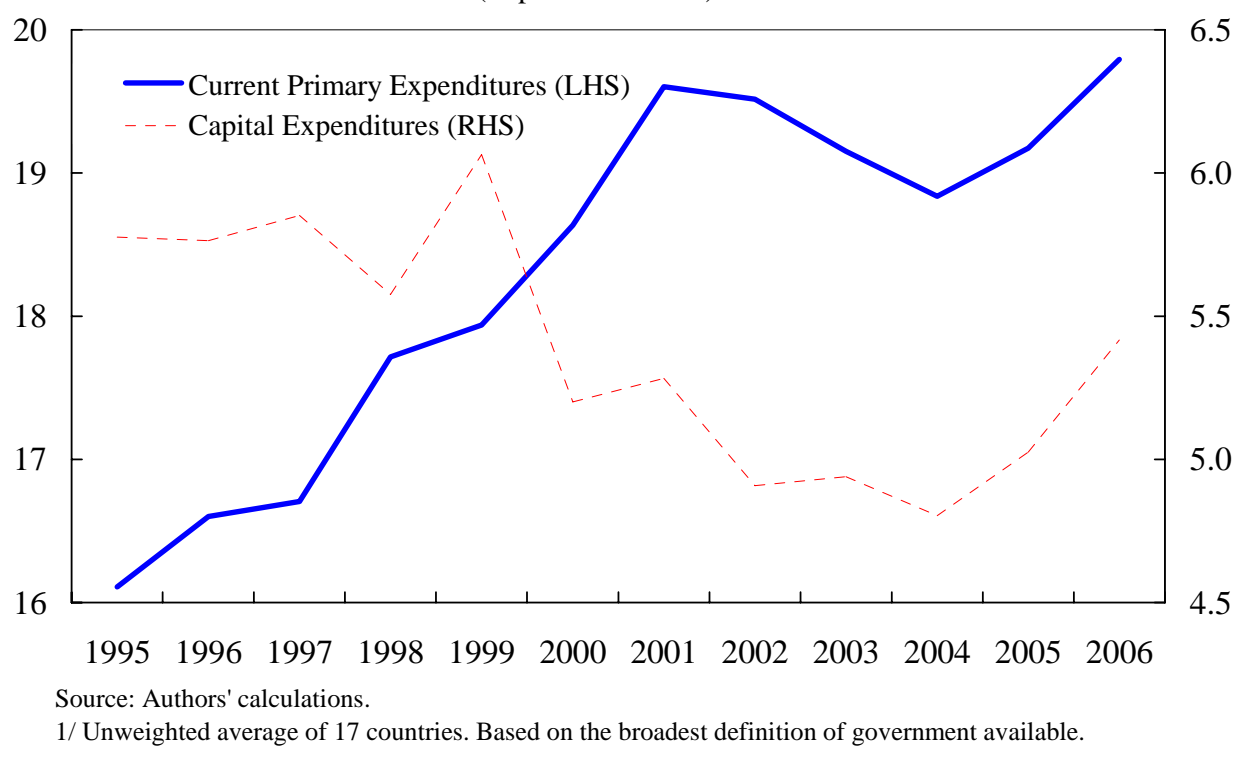

Figure 6. Latin America: Average Public Sector Capital Spending (In percent of primary expenditures) $1 /$

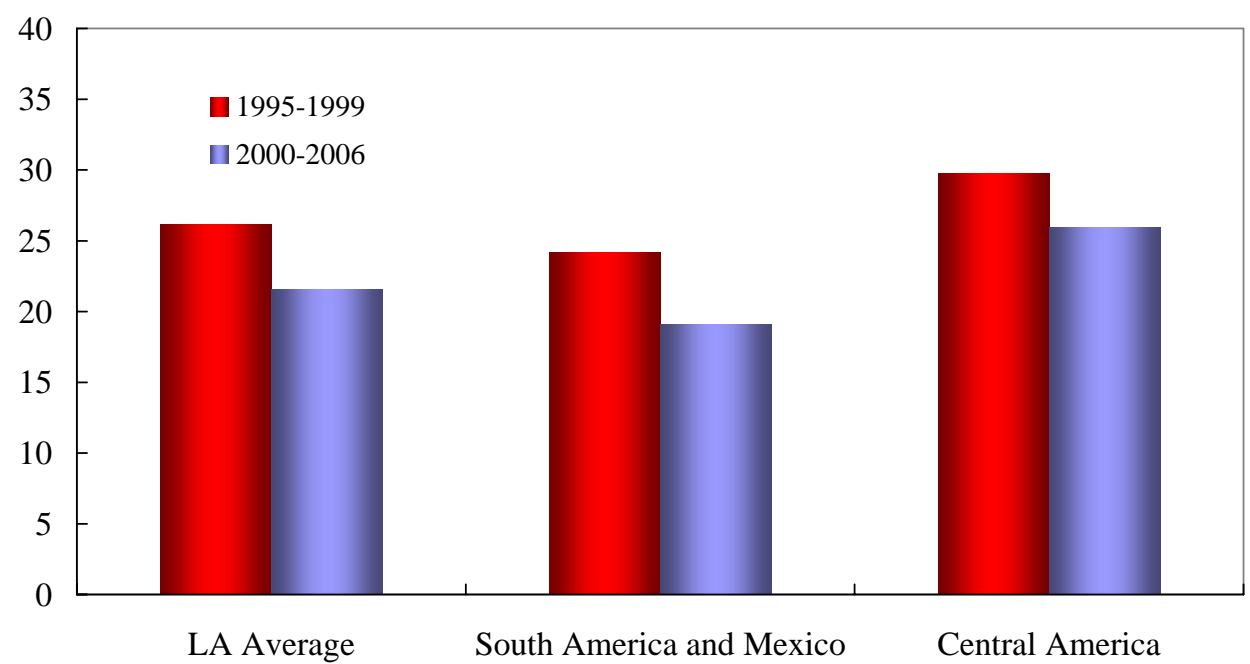

Source: Authors' calculations.

1/ Based on the broadest definition of government available. 
Social spending rose from the mid-1990s through 2004. A broad measure of social spending surged by about 2 percentage points of GDP through 2002 and then reversed somewhat (Figure 7). Outlays rose in all the countries covered in the sample, with the exception of Argentina and Ecuador. Higher spending for education and social insurance and assistance (including pensions) accounted for most of the increase. The bulk of these outlays was for current spending, and tracked the increase in total current outlays during the period. Especially large increases in social spending (above 6 percentage points of GDP) were realized in Bolivia, Colombia, and Honduras. In the case of the first two countries, social security and assistance outlays accounted for more than half the total increase, while in Honduras, education outlays were the main driver behind rising social expenditures.

Figure 7. Latin America: Trends in Social Spending (In percent of GDP) $1 /$

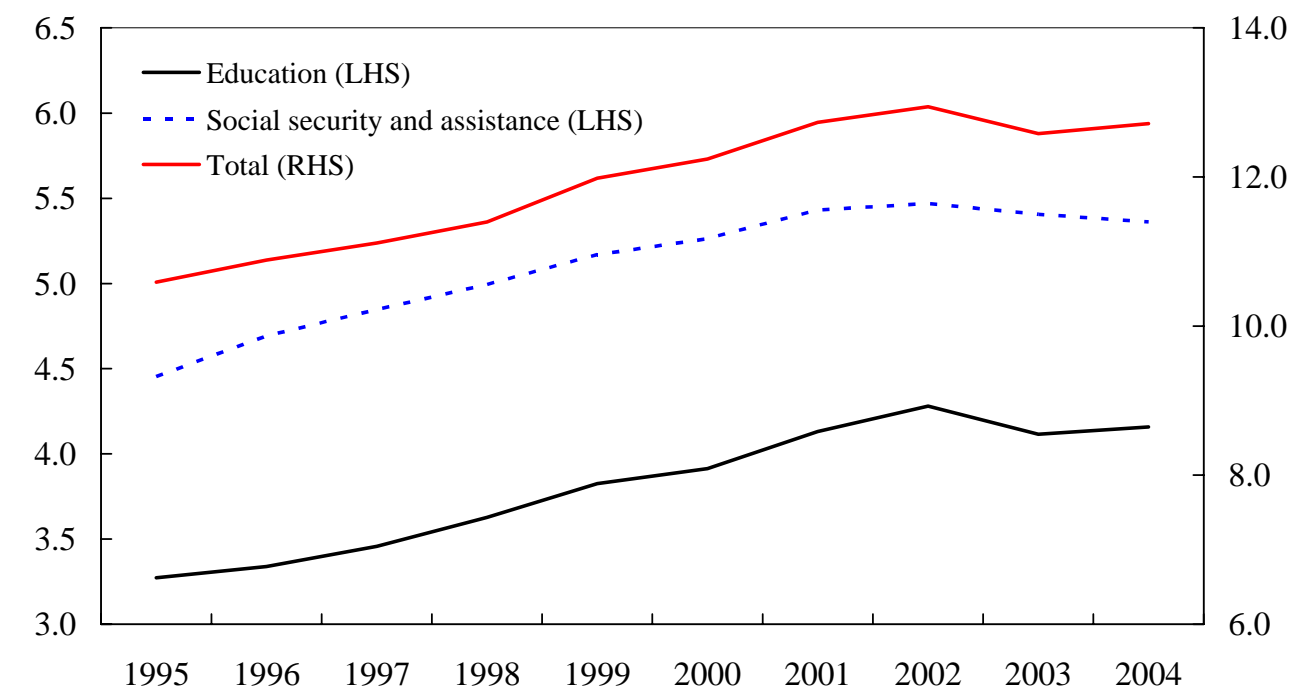

Sources: Social Indicators and Statistics database, ECLAC; national authorities; and IMF staff estimates. 1/ Unweighted averages for seventeen countries. 2004 data for Bolivia, Chile, Colombia, Peru, and Uruguay refer to 2003 data. 2004 data for Argentina are based on the national authorities; and for Honduras, 2002 and 2003 data are based on figures for 2001. For Peru, data for 2002 through 2004 for education and social security refer to 2001 data. For Colombia and El Salvador, data were provided by the national authorities.

In more recent years, social spending has fallen slightly as a ratio of GDP, even though real outlays have risen substantially. Comprehensive data for 2005 or 2006 are only available for five countries (Chile, Colombia, Mexico, Peru, and Uruguay). ${ }^{10}$ On average, spending has fallen by about $1 / 4$ percentage point of GDP in these countries, as high economic growth has more than compensated for a substantial increase in real outlays.

\footnotetext{
${ }^{10}$ Based on figures provided by country authorities and IMF staff estimates.
} 


\section{Key EXPenditure Policy Issues}

A comprehensive examination of the entire range of expenditure policy issues would be outside the scope of the present paper, including those related to public pension systems. ${ }^{11}$ In what follows below, we provide an overview of some of the key issues that are central to the debate on how to implement more pro-growth, pro-poor expenditure policies in the region.

\section{A. The Cyclicality of Government Spending}

\section{Procyclical fiscal policy has precluded a more rapid decline of public debt and vulnerabilities during economic recoveries. A number of studies have delineated the region's propensity for procyclical expenditure policies (Gavin and Perotti, 1997; Stein, Talvi, and Grisanti, 1998; Kaminsky, Reinhart, and Végh, 2004; Alesina and Tabellini, 2005; Talvi and Végh, 2005; Akitoby and others, 2006; Singh and Cerisola, 2006; and Sahay and Goyal, 2006). Spending trends in the recent recovery suggest the region has not fully escaped its legacy of procyclical fiscal policy, given the brisk acceleration of spending over the past two years.}

The cyclicality of spending varies across countries. Akitoby and others (2006), for example, identify the short- and long-term relationship between real output and government spending on a country-by-country basis for various expenditure categories. Their results indicate that in about two-thirds of Latin American countries, there is a statistically significant short-term relationship between shocks to real output and real primary expenditure, with spending and output moving procyclically — that is, in the same direction (Table 1). ${ }^{12,13}$ The results suggest that expenditure has been especially pro-cyclical in Costa Rica, Guatemala, and Venezuela. ${ }^{14}$

The cyclicality of spending also varies across expenditure category. As in Gavin and Perotti (1997), Akitoby and others (2006) find that capital outlays appear to be the most procyclical. Excluding the extremely high estimate for Bolivia, the average coefficient for the statistically significant observations in Table 1 is about 4.1, implying that a one percent

\footnotetext{
${ }^{11}$ For recent works addressing this theme, see Gill, Packard, and Yermo (2005) and Roldos (2006).

${ }^{12}$ This differs from the traditional approach to defining and measuring cyclicality, which assesses the impact of the cyclical position of the economy (rather than output shocks) on government spending. See Appendix I for further details.

${ }^{13}$ The possible endogeneity between spending and output was examined by the authors by performing a Durbin-Wu-Hausman test, using the first lag of output growth as an instrument. The figures reported in Table 1 exclude any results where, based on this test, endogeneity may be a concern.

${ }^{14}$ See Kaminsky, Reinhart, and Végh (2004) and Sahay and Goyal (2006) for an assessment of the relationship between the growth of real spending and output by country.
} 
shock to output boosts capital spending by about 4 percent. Spending on goods and services, by contrast, responds less markedly to shocks. Nevertheless, the average coefficient in most spending categories is higher than one for countries where there is a statistically significant relationship, indicating that spending responds more than proportionately to shocks. ${ }^{15}$

Table 1. Latin America: Estimates of the Short-Run Response of Spending to Output Shocks

\begin{tabular}{|c|c|c|c|c|c|c|c|}
\hline & $\begin{array}{l}\text { Total } \\
\text { Spending }\end{array}$ & $\begin{array}{l}\text { Primary } \\
\text { Spending }\end{array}$ & $\begin{array}{l}\text { Current } \\
\text { Spending }\end{array}$ & $\begin{array}{l}\text { Spending on } \\
\text { Goods and } \\
\text { Services } \\
\end{array}$ & $\begin{array}{l}\text { Wages and } \\
\text { Salaries }\end{array}$ & $\begin{array}{l}\text { Other Goods } \\
\text { and Services }\end{array}$ & $\begin{array}{l}\text { Capital } \\
\text { Spending }\end{array}$ \\
\hline Latin America 1/ & 1.57 & 1.79 & 1.22 & 1.37 & 1.52 & 2.06 & 5.91 \\
\hline Argentina & 0.86 & $1.95 * * *$ & $1.58 * *$ & $1.54 * * *$ & $1.33^{* * *}$ & $1.81^{* * *}$ & 2.32 \\
\hline Bolivia & 0.08 & 0.36 & -0.66 & -0.42 & -2.08 & 1.24 & $20.08 * *$ \\
\hline Chile & $0.61^{* *}$ & $0.86^{* * *}$ & $0.50^{* *}$ & $0.77 * * *$ & $1.00 * * *$ & 0.39 & $1.91^{* * *}$ \\
\hline Colombia & -0.98 & $\ldots$ & -1.23 & 0.64 & 0.74 & -0.63 & 0.63 \\
\hline Costa Rica & $1.60 * * *$ & $2.13^{* * *}$ & $1.44^{* *}$ & $1.15^{*}$ & $1.82 * * *$ & 0.71 & $2.62 * *$ \\
\hline El Salvador & 0.43 & 0.64 & 0.02 & 0.21 & -0.28 & 0.48 & 1.56 \\
\hline Guatemala & $2.77 * * *$ & $2.78 * * *$ & 1.00 & $1.82^{* *}$ & 0.27 & $\ldots$ & $5.95^{* * *}$ \\
\hline Mexico & 0.66 & $2.09 * * *$ & 0.31 & $1.96 * * *$ & $2.21 * * *$ & $\ldots$ & $3.06 * * *$ \\
\hline Nicaragua & 1.23 & 1.26 & 0.48 & -0.03 & 0.28 & $\ldots$ & $6.15^{* * *}$ \\
\hline Panama & $1.50 * * *$ & $0.72^{* *}$ & $1.35^{* * *}$ & $0.87^{* *}$ & -0.03 & $2.74 * * *$ & $5.10 * * *$ \\
\hline Paraguay & 0.59 & 0.61 & 0.34 & 0.62 & 0.19 & $1.65^{* * *}$ & 1.36 \\
\hline Peru & $0.66^{* *}$ & $1.15^{* * *}$ & 0.51 & $1.44 * * *$ & $0.82 *$ & $2.04 * * *$ & $1.83^{* * *}$ \\
\hline Venezuela & $2.30 * * *$ & $2.68 * * *$ & $\ldots$ & $\ldots$ & $1.92 * * *$ & 0.44 & $6.50 * * *$ \\
\hline \multicolumn{8}{|l|}{ Memorandum items: } \\
\hline with significant coefficent & 46.2 & 66.7 & 33.3 & 58.3 & 46.2 & 40.0 & 69.2 \\
\hline $\begin{array}{l}\text { Share significant for } 35 \\
\text { other developing countries }\end{array}$ & 31.3 & 40.0 & 40.0 & 48.4 & 28.1 & 31.0 & 45.2 \\
\hline $\begin{array}{l}\text { Average coefficient for } 35 \\
\text { other developing countries } 1 / 2 \text { / }\end{array}$ & 1.18 & 1.75 & 1.03 & 1.59 & 1.20 & 2.86 & 1.38 \\
\hline
\end{tabular}

The cyclicality of spending is higher than for other developing countries. The share of countries where spending is procyclical is higher in Latin America than for developing countries as a whole (Table 1), and average coefficient values are somewhat higher. Other studies also point to a more procyclical response of spending in Latin America. Singh and Cerisola (2006), for example, find a much higher correlation between the cyclical component of real spending and real GDP over 1990-2005 in Latin America than in Asia. Moreover, Gavin and Perotti (1997) find that government expenditure has been markedly more procyclical in Latin America than in industrial countries.

\footnotetext{
${ }^{15}$ The average coefficient (including for those estimates that were statistically insignificant) was generally lower, but still exceeded 1.0 for primary spending, other goods and services, and capital outlays.
} 


\section{The reaction of expenditures to macroeconomic developments is similar during} economic upswings and downswings. Recent research has emphasized the asymmetrical behavior of fiscal policy in developing countries (IMF, 2007). To assess the importance of this phenomenon in Latin America, the relationship between changes in output gaps and spending during good times (when output is above potential) and bad times (when output is below potential) was assessed. The (log) terms of trade was also added to the model to capture the effects of changes in the external environment. Results were estimated with both fixed effects and system GMM models; in the current context, the latter is the preferred model, given the presence of a lagged dependent variable and the potential endogeneity between output and spending. Table 2 indicates that the output gap has a statistically significant impact on spending. The estimated coefficients for positive and negative output gaps do differ over the cycle, but the differences are not statistically significant. This finding differs from that of earlier research, which indicated that expenditures have been particularly procyclical during economic downturns in the region (Gavin and Perotti, 1997). In developing countries as a whole, in contrast, a recent study suggests that spending has typically been procyclical in good times but countercyclical in bad times (IMF, 2007).

Table 2. Latin America: Response of Expenditure to Output Gaps

Dependent variable: Primary expenditures to GDP 1/

\begin{tabular}{|c|c|c|c|c|}
\hline \multirow[b]{2}{*}{ Lagged dependent variable } & \multicolumn{2}{|c|}{ Fixed Effects } & \multicolumn{2}{|c|}{ System GMM } \\
\hline & $\begin{array}{c}0.57 \\
(11.93)^{* * *}\end{array}$ & $\begin{array}{c}0.57 \\
(11.87)^{* * *}\end{array}$ & $\begin{array}{c}0.44 \\
(3.06)^{* * *}\end{array}$ & $\begin{array}{c}0.49 \\
(3.50)^{* * *}\end{array}$ \\
\hline Output gap 2/ & $\begin{array}{c}0.07 \\
(2.03)^{* *}\end{array}$ & & $\begin{array}{c}0.08 \\
(2.30)^{* *}\end{array}$ & \\
\hline Output gap (when positive) & & $\begin{array}{c}0.07 \\
(0.94)\end{array}$ & & $\begin{array}{l}-0.08 \\
(0.72)\end{array}$ \\
\hline Output gap (when negative) & & $\begin{array}{l}0.068 \\
(1.15)\end{array}$ & & $\begin{array}{c}0.17 \\
(1.78)^{*}\end{array}$ \\
\hline Log terms of trade & $\begin{array}{c}1.48 \\
(1.21)\end{array}$ & $\begin{array}{c}1.48 \\
(1.21)\end{array}$ & $\begin{array}{c}0.03 \\
(0.01)\end{array}$ & $\begin{array}{l}-0.25 \\
(0.09)\end{array}$ \\
\hline Lagged public debt to GDP & $\begin{array}{l}-0.003 \\
(1.03)\end{array}$ & $\begin{array}{l}-0.003 \\
(1.02)\end{array}$ & $\begin{array}{l}-0.005 \\
(0.67)\end{array}$ & $\begin{array}{l}-0.005 \\
(0.74)\end{array}$ \\
\hline Constant & $\begin{array}{c}3.55 \\
(0.63)\end{array}$ & $\begin{array}{c}3.54 \\
(0.63)\end{array}$ & $\begin{array}{l}12.66 \\
(1.20)\end{array}$ & $\begin{array}{l}12.96 \\
(0.93)\end{array}$ \\
\hline $\mathrm{R}^{2}$ & 0.87 & 0.87 & & \\
\hline Wald chi-square & & & 20.87 & 57.77 \\
\hline Hansen test & & & 14.97 & 11.87 \\
\hline P-value & & & 0.24 & 0.75 \\
\hline 2nd order autocorrelation & & & -0.91 & -0.89 \\
\hline P-value & & & 0.36 & 0.38 \\
\hline Number of observations & 237 & 237 & 237 & 237 \\
\hline
\end{tabular}

Source: Authors' calculations.

1/ Absolute value of t-statistics (z-statistics for system GMM results) in parentheses. * significant at 10\%; ** significant at 5\%; *** significant at 1\%. Z-statistics calculated using robust standard errors for the system GMM results, using the two-step system GMM routine in STATA. Period of estimation, 1989-2005. For some countries, data were not available for the entire time period. 2/ Output gap defined as ((actual output - potential output)/ potential output)*100. Potential output calculated using an HP filter for 1980-2010 data from the WEO database. 


\section{Developments in spending during the present economic recovery are broadly consistent} with these econometric results. Strong growth in recent years has brought output close to potential in many countries and, as predicted by the model, has increased spending-to-GDP ratios. As suggested by the small size of the coefficients, the estimated effect of cyclical developments on spending-to-GDP ratios is modest. Given observed changes in output gaps (of about 4 percentage points, on average, for the 17 countries), the model predicts that spending ratios would rise by about 0.5 percentage point of GDP between 2002 and $2006 .{ }^{16}$ This compares with the observed increase of 0.8 percentage point, which may indicate that the cyclicality of spending has increased relative to the sample average. As noted earlier, the modest response of spending-to-GDP ratios to the economic cycle-both in the model and recent outturns - conceals the high rapid growth of real government expenditures that has accompanied high rates of economic growth in recent years. In effect, these rapid spending increases have precluded a more decisive decline in debt ratios during the present recovery.

\section{B. Public Investment}

Public investment has been low relative to other developing regions. On the basis of national income accounts data, public investment averaged about $4 \frac{1}{2}-5$ percent of GDP over 1990-2006 — considerably less than the levels prevailing in Asia and Africa, but higher than Central and Eastern Europe (Table 3). Even after taking into account the significant participation of the private sector in infrastructure spending (about 2 percentage points of GDP, according to the most recently available data), this spending still lags behind that of other regions. ${ }^{17}$ From the late-1990s until recently, Latin American capital spending has tended to decline in relation to GDP. This decline in part reflected the wave of privatizations in the region during the 1990s, which have not, in practice, been fully offset by increased private investment in the affected sectors (Fay and Morrison, 2005).$^{18}$ In other regions, public investment has also fallen slightly or remained broadly constant in relation to GDP.

\footnotetext{
${ }^{16}$ Calculations are based on the system GMM coefficient estimate of the relationship between the output gap and primary spending-to-GDP ratios (0.08). Changes in output gaps were estimated on the basis of changes in actual and potential output, with the latter estimated by an HP filter (see Table 2).

${ }^{17}$ Based on available data on infrastructure spending from the World Bank for seven countries (Argentina, Bolivia, Brazil, Colombia, Chile, Mexico, and Peru) for 2000-01. See Appendix II for details.

18 The precise impact of privatization on public and private infrastructure investment in the region is difficult to quantify. In countries where public infrastructure investment declined between the mid-1990s and 2000-01 (Argentina, Bolivia, Brazil, and Mexico)—due either to privatization or other reasons_private investment in infrastructure failed to fully compensate for this decline; on average, overall public and private investment in infrastructure declined in these countries by close to $1 / 2$ percentage point of GDP during the second half of the 1990s.
} 
Table 3. Public Investment in Latin America and Other Regions, 1990-2006

\begin{tabular}{|c|c|c|c|c|}
\hline & 1990-94 & 1995-99 & $2000-04$ & $2005-06 \quad 2 /$ \\
\hline Latin America & 4.7 & 4.9 & 4.3 & 4.5 \\
\hline Africa & 7.9 & 7.7 & 7.6 & 8.2 \\
\hline Asia & 9.1 & 8.7 & 8.1 & 8.4 \\
\hline Central and Eastern Europe & 3.6 & 3.8 & 3.8 & 3.8 \\
\hline $\begin{array}{l}\text { Memorandum item: } \\
\text { Latin America, public sector } \\
\text { capital expenditure 3/ }\end{array}$ & $\ldots$ & 5.7 & 4.7 & 5.0 \\
\hline
\end{tabular}

Sources: Authors' calculations, based on the WEO database.

1/ Refers to public investment as measured in the national accounts data. Data are not available for all countries during the 1990s and for 2006. For Latin America, data cover 15 countries, as figures for Costa Rica and Nicaragua are not available for the early 1990s.

2/ Data not available in 2005-06 for Korea and in 2006 for Hungary and Poland. In these cases, data from the most recent year available were used.

3/ Based on data for the nonfinancial public sector or widest definition of government for 15 countries.

Deficiencies in infrastructure - and the need for additional infrastructure investmentvary by country. As suggested in Figure 8 , the quality of infrastructure in some countries in the region is higher than predicted by their level of economic development, notably in Chile, El Salvador, and Panama. In Paraguay and Argentina, on the other hand, infrastructure lags are sizable.

\section{Inefficiencies in public investment are contributing to infrastructure lags. A} nonparametric production function approach was employed to compare the efficiency of spending for seven countries (Appendix II). This allows for an analysis of the relationship between spending and outcomes (in terms of improvements in infrastructure) across countries and reveals a wide range of performance. Using this approach, spending appears most efficient in Chile and Mexico, while the returns from spending in Bolivia and Colombia are much less favorable. In the case of Colombia, this result should be interpreted with caution, given that public investment may have been overstated in the national income accounts in the 1990s (which would tend, ceteris paribus, to lower efficiency scores) ${ }^{19}$ in a similar vein, recent improvements in the framework for managing public-private partnerships, also suggest that the efficiency of infrastructure spending in Colombia may be stronger than indicated by our results. Countries relying more heavily on the public sector for the provision of infrastructure services appear to be less efficient (Figure 9), as well as those where aggregate public infrastructure spending is relatively high. ${ }^{20}$

\footnotetext{
${ }^{19}$ Public investment in the national income accounts has recently been revised downward for 2003 onward, owing to the overstatement of public investment by local governments. Revised data are not available for earlier years, but it is likely that spending was overestimated in earlier years as well.

${ }^{20}$ This also suggests that for countries where the share of the private sector has increased by more than the sample as a whole (Argentina, Chile, Colombia, and Peru), the results may overestimate their present degree of inefficiency.
} 
Figure 8. Latin America: Institutional and Infrastructural Performance - Deviation of Actual Indices from Values Predicted by PPP-adjusted Per Capita Income

(In percent of the average standard deviation of the residuals) 1/
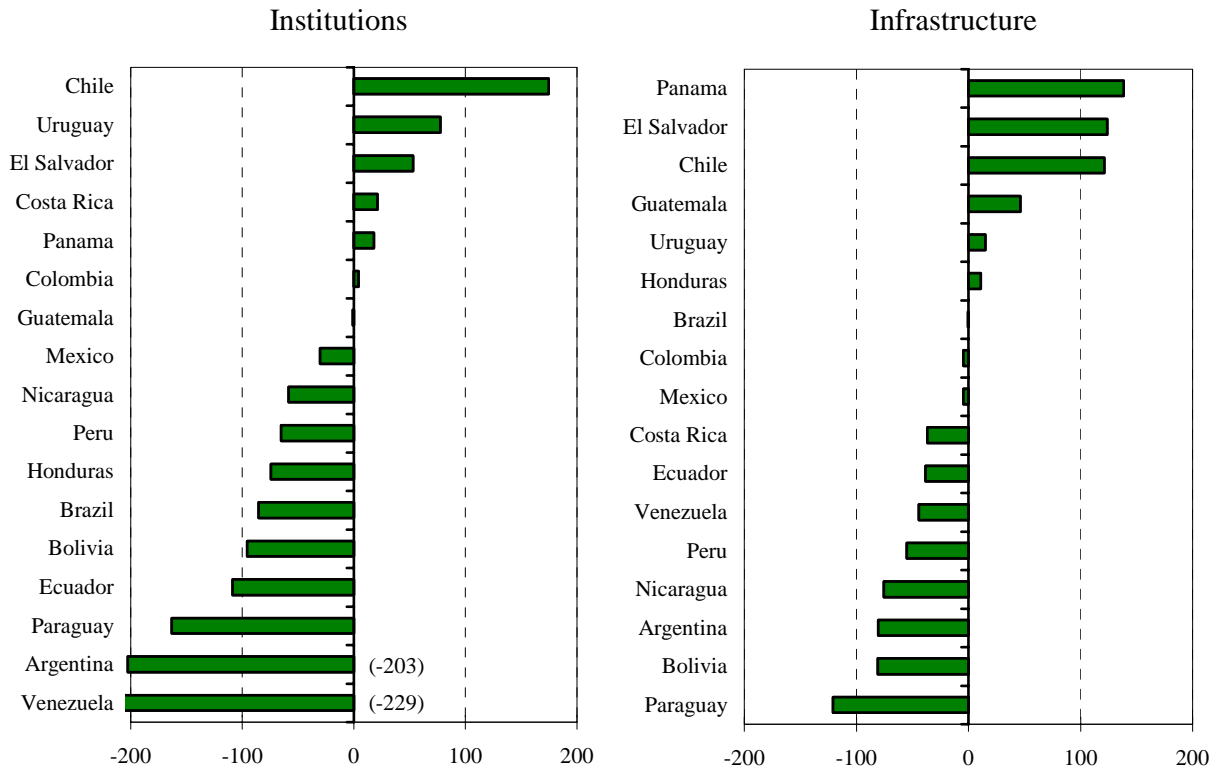

Source: Authors' calculations, based on Lopez-Claros and others (2006).

1/ Residuals derived from a regression of the index score on institutions (infrastructure) and real GDP per capita in PPP terms for 125 countries.

\section{Figure 9. Latin America: Public Share of Infrastructure Spending and Efficiency}

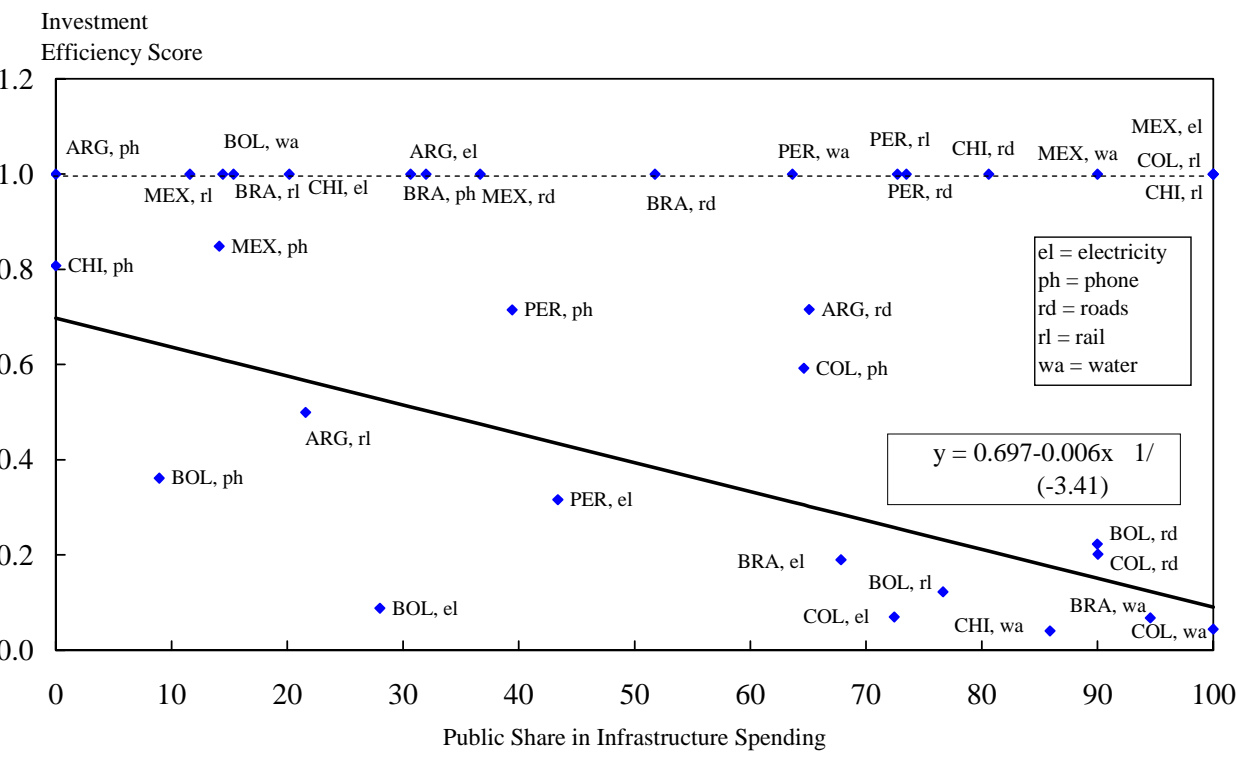

1/ z-score in parentheses. Coefficients based on a truncated regression model with an upper bound of 1.0. Note: Efficiency scores range from 1.0 (most efficient) to zero. Each observation represents a country's efficiency score in a given sector (electricity, rails, roads, telecommunications, and water). See Appendix II for further details. 


\section{Weaknesses in public institutions and the volatility of capital spending also contribute to inefficiencies in investment spending. There is considerable scope to improve project} selection and project appraisal in the region (IMF, 2005). More generally, Figure 8 suggests that lags in institutional development are highly correlated with poor infrastructure. The volatility of capital spending may also contribute to inefficiencies if it leads to erratic cash flows to contractors and disrupts regular maintenance outlays (Fay and Morrison, 2005).

\section{Public Sector Employment}

Public sector wage bills are generally comparable to those in other regions. At the general government level, spending for public wages is similar to or lower than that of many other developing regions (Table 4) ${ }^{21}$ However, there is wide variance in the level of spending across the region, with spending in 2005 ranging from 121/2 percent of GDP in Honduras to $41 / 2$ percent of GDP in Nicaragua, compared with the Latin American average of 7 percent of GDP in 2004-05. The ratio of average public sector wages relative to the manufacturing sector is also in line with other regions. And, while recent data are not readily available, figures from the 1990s suggest that public sector employment levels in Latin America are not particularly high (Table 5).

Table 4. General Government Wages and Salaries in Latin America and Other Regions, 2004 1/

\begin{tabular}{lcccc}
\hline & $\begin{array}{c}\text { Wages, as a } \\
\text { percent of } \\
\text { GDP }\end{array}$ & $\begin{array}{c}\text { Wages, as a } \\
\text { percent of general } \\
\text { government } \\
\text { expenses }\end{array}$ & $\begin{array}{c}\text { Average central } \\
\text { government wage to } \\
\text { per capita GDP 2/ }\end{array}$ & $\begin{array}{c}\text { Ratio of public to } \\
\text { manufacturing sector } \\
\text { wages 2/ }\end{array}$ \\
\hline Latin America 3/ & $\mathbf{7 . 0}$ & $\mathbf{3 2 . 8}$ & $\mathbf{2 . 1}$ & $\mathbf{1 . 5}$ \\
Emerging Asia 4/ & 5.7 & 32.9 & 3.0 & 1.8 \\
Eastern Europe and Central Asia & 7.9 & 23.6 & 1.3 & 0.6 \\
Middle East and North Africa 5/ & 10.6 & 41.9 & 3.4 & 1.0 \\
Sub-Saharan Africa 6/ & 9.6 & 30.8 & 5.7 & 2.0 \\
OECD & 12.1 & 26.4 & 1.6 & 1.6 \\
\hline
\end{tabular}

Sources: Government Financial Statistics, IMF; World Bank database on government employment and wages; and Schiavo-Campo, de Tommaso, and Mukherjee (1997).

1/ 2004 or latest available year. Country coverage varies by category.

2/ Data refers to 1990s only, except for Latin American central government wage, which is based on the latest year between 1996 and 2000 for which data are available. Ratio of public to manufacturing sector wage data for Latin America includes Caribbean countries. 3/ See text for description of data on wages.

4/ The Emerging Asia sample includes Hong Kong SAR, Macao SAR, India, Malaysia, Singapore, and Thailand. Malaysia refers to central government.

5/ Budgetary central government for nine countries.

6/ Central government for eight countries.

\footnotetext{
${ }^{21}$ Data on general government wage bill outlays in developing countries are not widely available. Data for Guatemala and Panama refer to the central government only. In the case of Mexico, wages paid by public enterprises are included.
} 
Table 5. General Government Employment in Latin America and Other Regions, 1990s 1/

\begin{tabular}{lcccc}
\hline & $\begin{array}{c}\text { Number of } \\
\text { countries }\end{array}$ & $\begin{array}{c}\text { General government } \\
\text { employment as percent of } \\
\text { population }\end{array}$ & $\begin{array}{c}\text { General government } \\
\text { countries }\end{array}$ & $\begin{array}{c}\text { employment as percent of } \\
\text { total employment }\end{array}$ \\
\hline Latin America 2/ & $\mathbf{9}$ & $\mathbf{3 . 0}$ & $\mathbf{1 0}$ & $\mathbf{2 0 . 4}$ \\
Asia & 11 & 2.6 & 3 & 17.2 \\
Eastern Europe and Central Asia & 17 & 6.9 & 15 & 42.3 \\
Middle East and North Africa & 8 & 3.9 & 4 & 50.3 \\
Sub-Saharan Africa & 20 & 2.0 & 8 & 28.4 \\
OECD & 21 & 7.7 & 15 & 21.0 \\
\hline
\end{tabular}

Sources: Schiavo-Campo, de Tommaso and Mukherjee (1997), Hammouya (1999), and OECD (2001).

1/ Latest data for 1990s, except for the share of general government employment in population, which is for the early 1990 s.

2/ Includes Caribbean.

\section{The quality of government services is lower than in many fast-growing regions of the} world (Table 6). The lower quality of services reflects, to a large extent, the region's less advanced level of development. On average, the quality of services in Latin America is in line with that predicted by income levels (Figure 10). At the same time, there are some important differences across countries. In particular, bureaucratic quality in Chile and Mexico is about 35-40 percent higher than predicted by income levels (more than one standard deviation above fitted values). In Paraguay and Venezuela, on the other hand, the quality of the bureaucracy falls short of fitted values by more than one standard deviation. A recent assessment by the IADB (reported in IADB, 2005 and Echebarría and Cortázar, 2006) also indicates a wide variation in the quality of bureaucracies in the region; in Brazil and Chile, the civil service is well functioning, but in over half of the countries of the region, systems are inadequate to attract qualified staff and ensure the efficient performance of employees.

Table 6. Government Effectiveness in Latin America and Other Regions

\begin{tabular}{lll}
\hline & $\begin{array}{l}\text { ICRG Bureaucratic Quality } \\
\text { Index (2005) 1/ }\end{array}$ & $\begin{array}{l}\text { WB Measure of Government Effectiveness } \\
\text { (Percentile Ranking 2005) 2/ }\end{array}$ \\
\hline Latin America & $\mathbf{2 . 0}$ & $\mathbf{4 3 . 4}$ \\
Asia & 2.5 & 47.2 \\
Eastern Europe \& Baltics & 2.5 & 61.7 \\
Middle East and North Africa & 2.3 & 45.0 \\
Sub-Saharan Africa & 1.3 & 27.0 \\
OECD & 3.7 & 88.0 \\
\end{tabular}

Sources: Kaufmann, Kraay, and Mastruzzi (2006) and the International Country Risk Guide database.

$1 /$ Index ranges in value from zero to a maximum value of 4.

2/ Regional averages based on the percentile ranking for individual countries. The regional average for the OECD of 88 percent, for example, indicates that the average measure of government effectiveness for an OECD country is better than 88 percent of all countries. 
Figure 10. Relationship Between GDP Per Capita

Bureaucratic and Bureaucratic Quality

Quality Index

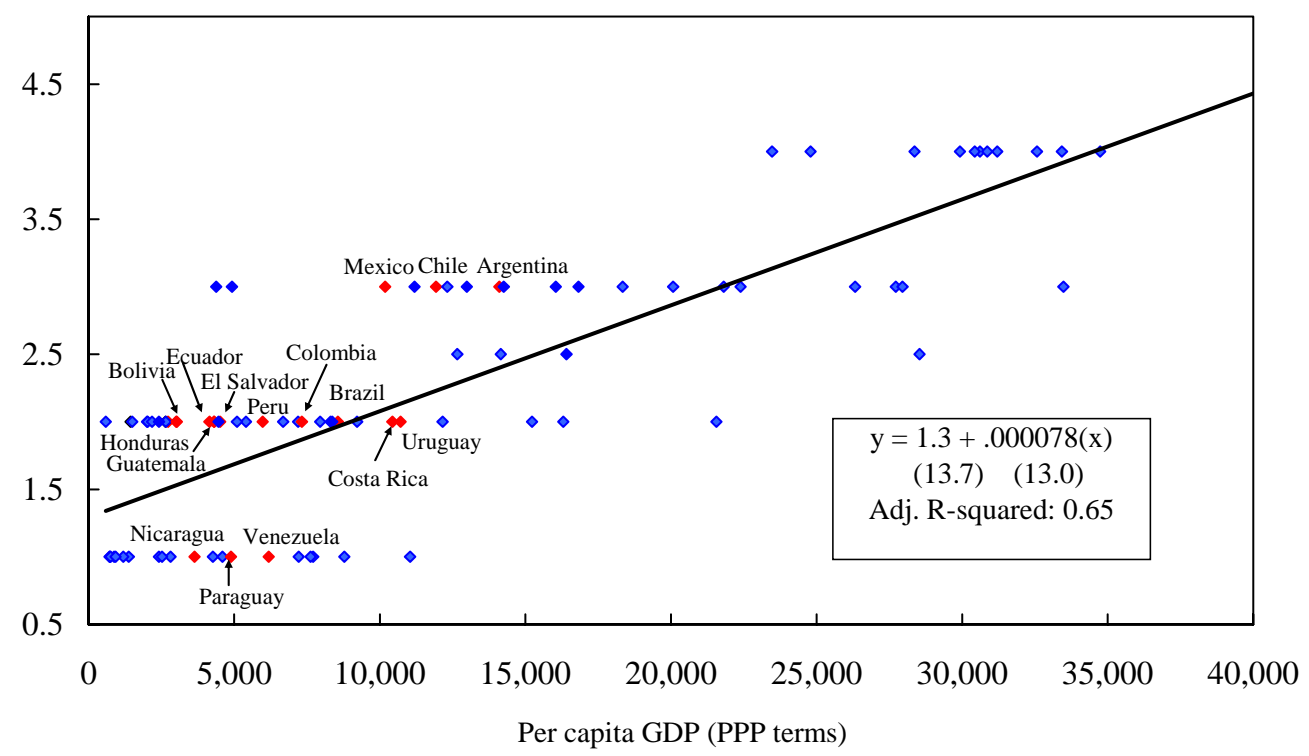

The quality of government has not improved in Latin America since the late 1990s. The quality of services, as measured by the ICRG index of bureaucratic quality, increased steadily between 1990 and 1998, but has generally been flat thereafter (Figure 11). After converging toward levels prevailing in Eastern Europe and the Baltics and Asia, differentials with these regions have remained broadly constant this decade. The World Bank's measure of government effectiveness paints a more negative picture, with Latin America posting a decline in both absolute and relative terms between 1998 and 2005 (Figure 12). This contrasts with the Eastern European and Baltic states, which, according to this index, have secured significant gains in government effectiveness. 
Figure 11. The Quality of the Bureaucracy (ICRG Index, 1990-2005)

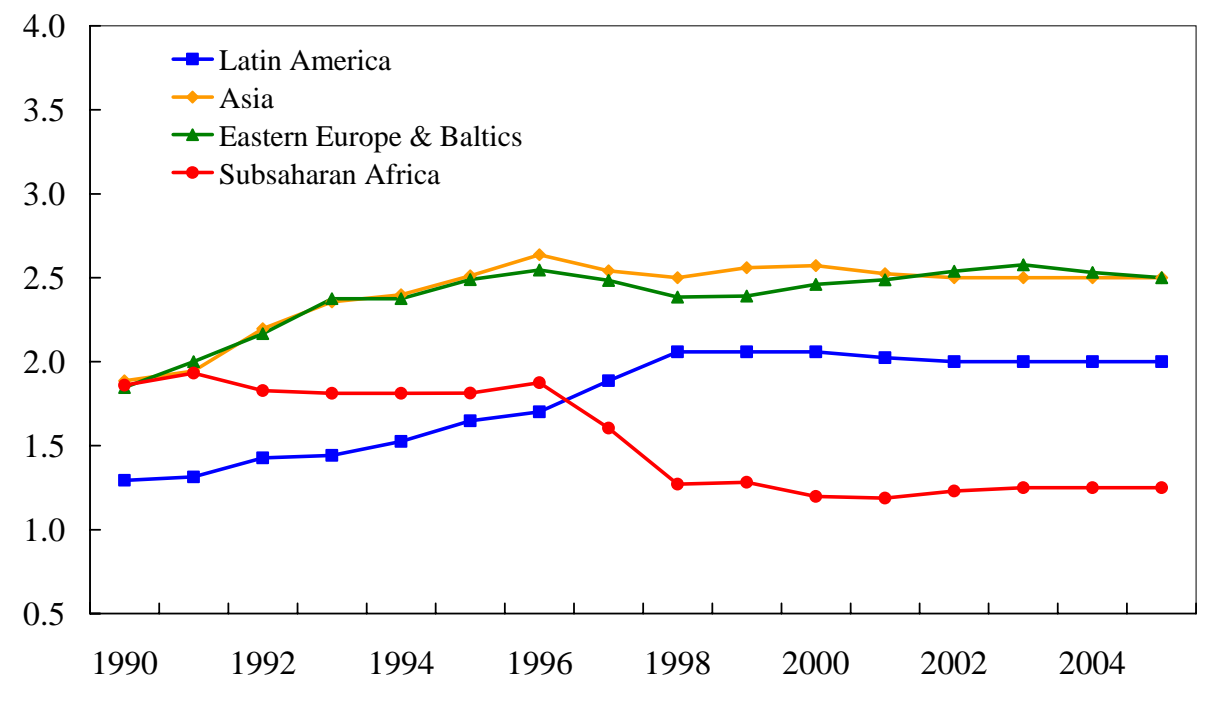

Source: The International Country Risk Guide database.

Figure 12. Government Effectiveness

(In percentile rank, 1996-2005)

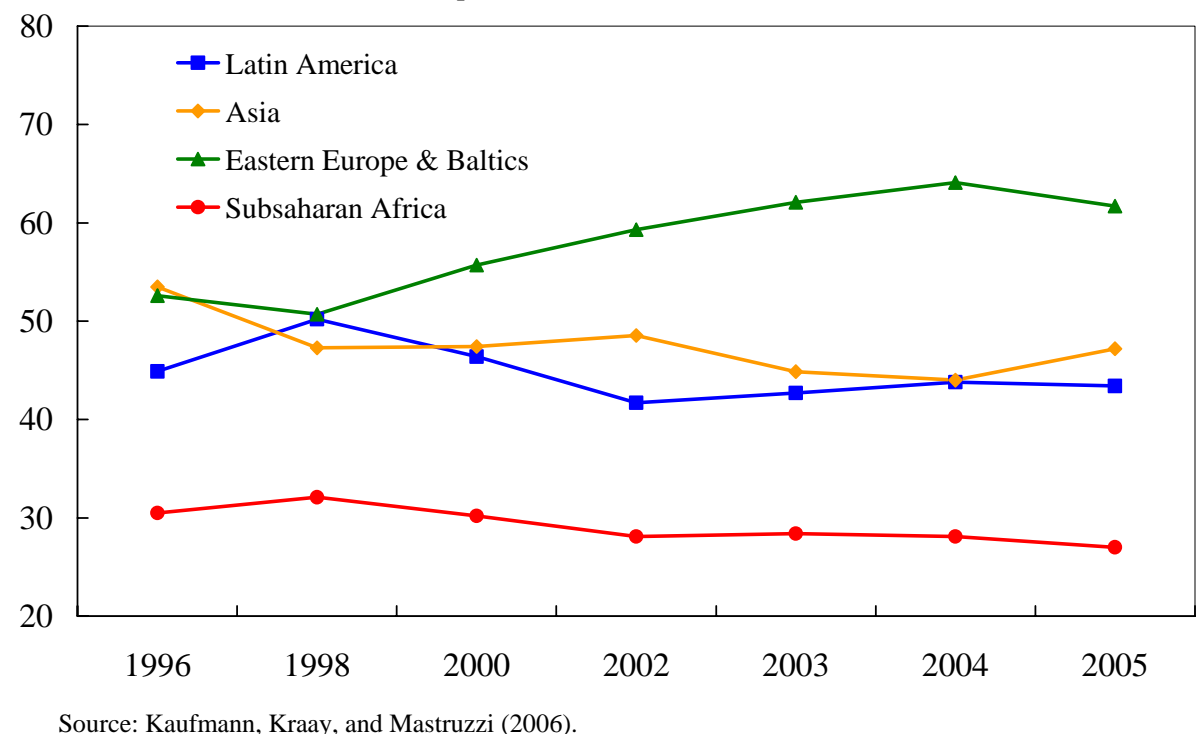

While average wage bills are relatively modest in Latin America, the low and declining quality of public services suggests there is ample room to improve the efficiency of spending on public employment. Improving the quality of the civil service is a complex task. Cross-country evidence suggests that increasing the generosity of average public sector pay is unlikely to be part of the solution, unless accompanied by reforms that aim to establish merit-based bureaucracies and address the core weaknesses of administrations in the region. A cross-country regression of the determinants of government quality, for example, reveals 
that average wages have no statistically significant effect after controlling for per-capita income. ${ }^{22}$ In addition, within Latin America, there is no statistically significant correlation between increases in the general government wage bill (as a share of GDP) and improvements in bureaucratic quality over the 1996-2005 period. As such, reform efforts should center on tackling the institutional weaknesses that plague many countries in the region, including patronage in hiring and promotions, the absence of performance evaluation, and internal inequities in remuneration (i.e., different pay for similar jobs) (IADB, 2005 and Echebarría and Cortázar, 2005).

\section{Social Spending}

Social spending absorbs a large share of total government outlays. At about 13 percent of GDP, these outlays account for half of primary government spending. ${ }^{23}$ Spending is higher than in Emerging Asia, but lower than the OECD and Eastern Europe and Central Asia (Table 7). The differences across country groups are largely explained by the differing sizes of their social protection spending, which mostly comprises pension benefits. ${ }^{24}$

Table 7. General Government Social Spending in Latin America and Other Regions, 2004 (In percent of GDP) 1/

\begin{tabular}{|c|c|c|c|c|c|}
\hline & Education & Health & $\begin{array}{c}\text { Social } \\
\text { protection }\end{array}$ & $\begin{array}{l}\text { Housing and community } \\
\text { amenities }\end{array}$ & Total 2/ \\
\hline Latin America 3/ & 4.2 & 2.6 & 5.4 & 0.9 & 12.7 \\
\hline Emerging Asia 4/ & 3.5 & 1.3 & 2.2 & 1.1 & 8.4 \\
\hline Eastern Europe and Central Asia & 4.8 & 4.4 & 12.1 & 1.5 & 22.8 \\
\hline Middle East and North Africa 5/ & 4.2 & 2.0 & 1.8 & 1.1 & 9.1 \\
\hline Sub-Saharan Africa 6/ & 5.5 & 2.9 & 3.7 & 0.5 & 13.8 \\
\hline OECD & 6.4 & 6.9 & 17.3 & 0.8 & 32.6 \\
\hline
\end{tabular}

Sources: Government Financial Statistics, IMF; Social Indicators and Statistics database, ECLAC; national authorities; and IMF staff estimates.

1/ 2004 or latest available year.

2/ Number of observations vary by category. Therefore, the total social spending regional averages may not necessarily equal the sum of the regional averages of the spending components.

3/Unweighted averages for seventeen countries. 2004 data for Bolivia, Chile, Colombia, Peru, and Uruguay refer to 2003 data. 2004 data for Argentina are based on the national authorities and IMF staff estimates; and for Honduras, 2002 and 2003 data are based on figures for 2001. For Peru, data for 2002 through 2004 for education and social security refer to 2001 data. For Colombia and El Salvador, data were provided by the national authorities.

4/ The Emerging Asia sample includes Hong Kong SAR, Macao SAR, India, Korea, Singapore, Thailand and Vietnam. Korea and Thailand refer to central government.

5/ Budgetary central government for eight countries.

6/ Central government for seven countries.

\footnotetext{
${ }^{22}$ Average wages were derived using the average civil servant wage as a share of per capita income reported in Table 4. Details on these estimates are available from the authors upon request.

${ }^{23}$ Social spending comprises outlays for education; health; social protection (including both social insurance and social assistance programs, such as school lunch programs); and housing and community amenities.

${ }^{24}$ Comparisons across regions should be made with some caution, given the small sample size available for general government data. Central government data have been included in the comparator groups in Table 7 in cases where social spending is highly centralized.
} 


\section{Substantial levels of social spending have coincided with mixed results on social} indicators. Education and health indicators are broadly in line with the region's level of development (ECLAC, 2006a). Primary and secondary school enrollment rates have climbed since the 1990s, as well as health indicators such as access to clean water, immunization rates, and infant mortality rates. Nevertheless, there are significant lags in human capital relative to the industrial countries and fast-growing regions of the world. Net secondary school enrollment rates, for example, stand at around 60 percent, compared with 70 percent in a sample of 28 emerging market and Caribbean countries.

Inefficiencies in public spending have retarded gains in social indicators. In education, repetition rates - a common measure of inefficiency - are high relative to comparator countries. ${ }^{25}$ While relatively few Latin American countries have participated in such exercises, education systems have also fared poorly in international examinations assessing comprehension of science and mathematics, suggesting that the quality of education is also weak in the region. ${ }^{26}$

The volatility of social spending may also be limiting its effectiveness. Social spending has been procyclical, and even more volatile than aggregate spending (ECLAC, 2006a). This may also have impeded the efficiency of spending, as achieving substantial progress in health and education requires sustained effort over several decades (ECLAC, 2006b). Looking ahead, this suggests that further progress in reducing macroeconomic volatility will also be helpful in improving the efficiency of the public sector.

Despite high social spending, poverty rates remain high and are the region's most glaring developmental lag. At an estimated 41 percent of the population in 2005, poverty exceeds the level predicted by the region's level of development (ECLAC, 2006a), owing to high levels of income inequality. On the basis of the most recent data available, Gini coefficients for the region average over 0.50 (see ECLAC, 2006a), compared with about 0.40 and 0.35 in Asia and the OECD, respectively, during the 1990s (de Ferranti and others, 2004). Other measures also confirm that inequality in Latin America is higher than in any other region of the world, with the possible exception of Sub-Saharan Africa (de Ferranti and others, 2004).

\section{It appears that much of the region's social spending has been poorly targeted, limiting} its benefits for the poor. On average, social spending has been regressive, with the poorest

\footnotetext{
${ }^{25}$ Repetition rates are proxied by differences in gross and net secondary enrollment rates.

${ }^{26}$ For an examination of education in Latin America, see de Ferranti and others (2003); and for evidence on performance on international examinations, OECD (2004), and Mullis, Gonzalez and Chrostowski (2004a, 2004b). Herrera and Pang (2005) examine the efficiency of education and health spending in Latin America using a technique similar to the one used here to assess the efficiency of investment spending.
} 
20 percent receiving less than a fifth of the benefits of these outlays (Table 8). The targeting of spending has varied by country, with more progressive outlays in Chile, Costa Rica, and Uruguay, and a more regressive pattern of benefits in Bolivia, Peru, and Nicaragua (ECLAC, 2006a). In practice, the distributive effect of this spending has been modest in most countries, although Argentina, Costa Rica, and Brazil are exceptions to this rule (ECLAC, 2006a). Comparisons with other regions on the incidence of spending are problematic, given the small number of studies examining total social expenditures. ${ }^{27}$ Available evidence, however, suggests that education and health spending are even more regressive in other developing regions (Davoodi, Tiongson, and Asawanuchit, 2003).

\section{The distributive incidence of spending also varies significantly for different types of} spending. A high share of the benefits from outlays on higher education and social insurance outlays accrue to upper-income groups, while primary education and social assistance highly benefit the poor (de Ferranti and others, 2004; ECLAC, 2006a; Lindert, Skoufias, and Shapiro, 2006).

\section{Targeted social assistance programs have expanded in recent years and have shown} promising results. These programs often make cash assistance conditional on steps by recipients to send family members to school or other actions that improve the prospects for escaping poverty on a long-term basis. Examples of these programs include the Jefes y Jefas de Hogar and Familias programs in Argentina, Bolsa Familia in Brazil, Chile Solidario in Chile, Familias en Acción in Colombia, and Oportunidades in Mexico. In practice, these conditional transfer programs have been highly effective and well-targeted to the poor (Lindert, Skoufias, and Shapiro, 2006), and can be helpful in achieving significant improvements in the welfare of the poor. In Brazil, for example, the expansion of the Bolsa Familia during 2003 and 2005 contributed to a narrowing of income gaps between the rich and poor and a reduction in poverty rates (Centro de Políticas Sociais, 2006). In most countries, spending on these and other social assistance remains modest (averaging about 1$1 \frac{1}{2}$ percent of GDP) and comprises a small share of total social spending.

\footnotetext{
${ }^{27}$ See Chu, Davoodi, and Gupta (2000) for a discussion of the evidence on the targeting and progressivity of different types of social spending in developing countries.
} 
Table 8. Latin America: Distribution of Benefits from Social Spending to the Top and Bottom Quintiles 1/

\begin{tabular}{lcc}
\hline & Poorest quintile & Richest quintile \\
\hline Education & 20.2 & 20.4 \\
$\quad$ Primary & 29.0 & 7.9 \\
Secondary & 13.2 & 18.3 \\
$\quad$ Tertiary & 1.9 & 52.1 \\
Health & 20.6 & 17.6 \\
Social security & 5.6 & 51.2 \\
Total social spending & 15.0 & 30.4 \\
& & \\
Memorandum item: & & 56.4 \\
Share of quintiles & 3.6 & \\
in primary income & \\
Source: Authors' calculations, based on ECLAC (2006a). & \\
1/ Unweighted average. Country coverage varies by category. For total spending, total education, health, and social \\
security spending, the number of countries covered is eight, thirteen, fourteen, and nine, respectively.
\end{tabular}

\section{SUMmary AND Policy IMPlications}

Primary expenditures have trended upward since the mid-1990s, driven by increases in current spending. The increase in spending owes largely to nonwage outlays, including for social insurance. At the same time, capital expenditures have remained at low levels in most years, with the exception of 2006. Despite recent increases, public investment remains low relative to most developing regions of the world.

There is substantial scope to improve the efficiency of government expenditure. The ability of countries to translate spending on public investment into tangible gains in the provision of infrastructure varies markedly across countries. This suggests that large efficiency gains are possible by adopting the best practices of the most efficient countries of the region. Greater reliance on the private sector for the provision of infrastructure could also boost efficiency in some cases, although this may also require a strengthening of the institutional framework for private investment (IMF, 2005, 2006a). ${ }^{28}$ The region's lackluster ratings on institutional quality and government services also suggest opportunities to improve the efficiency of spending on government employment. Countries with high wage bills (as a share of GDP) do not necessarily enjoy better government services, suggesting that higher wages are unlikely, by themselves, to lead to better government services. Inefficiencies are also manifest in social spending, as the education system in many countries is characterized by high rates of repetition and, in some countries, poor performance on international examinations.

${ }^{28}$ A strong institutional framework is also required to ensure that the fiscal risks of public-private partnerships are adequately managed and that these partnerships are driven by efficiency considerations, rather than a desire to bypass normal budgetary procedures. See IMF (2006a). 
The region's recent experience suggests a clear roadmap for forging a more pro-poor pattern of social spending. The region continues to suffer high rates of income poverty and high rates of underlying income inequality. In the past, social spending has done relatively little to alleviate this inequality, as most social spending is regressive. The share of spending accruing to the poorest 20 percent of households varies markedly by spending category, however. Some spending is fairly well targeted, such as outlays for primary education and social assistance programs, while other spending, such as that for higher education and social insurance, provide only modest benefits for the poor. In this light, options for achieving a more pro-poor pattern of spending include the continued reform of public social insurance schemes to reduce their generosity and place them on an actuarially sound footing (thus reducing their share of social spending over the longer term); increased user fees for higher education, combined with subsidies for low-income families to ensure their access; improving the quality of secondary education to reduce secondary school repetition rates; and expansion of targeted social assistance programs.

\section{Addressing the procyclical tendencies of spending remains a challenge for the region.} After being well contained in the early phases of the present economic recovery, the growth of real spending accelerated in 2005-06, in line with the region's legacy of procyclical fiscal policy. The increase in spending-to-GDP ratios during the current recovery has been beyond that predicted by past experience. Moreover, small changes in spending-to-GDP ratios mask the rapid growth of real spending. Reducing the procyclicality of expenditure will require a further strengthening of political resolve to limit spending growth during good times. In this context, explicit ceilings for expenditure growth, while leaving the automatic stabilizers on the revenue side free to operate, could be helpful, including as a signaling device of government commitment to fiscal discipline (see Debrun and Kumar, 2006 and IMF, 2007). Indeed, numerical restrictions on fiscal variables (which include fiscal rules for the growth of expenditures, deficits, and debt) have been associated with better fiscal performance in the region (Filc and Scartascini, 2006). At the same time, compliance-including for expenditure rules-has been uneven. This underscores the need for well-designed sanctions and political commitment to make them effective. Beyond expenditure rules, the reduction of public debt to prudent levels would also help curb procyclicality by reducing the probability of macroeconomic crises and the need for sharp fiscal contractions to restore debt sustainability and market confidence. Further improvements in the structure of debt-including the lengthening of maturities and greater reliance on debt issued in domestic currency-could also help obviate the need for contractionary expenditure policies during economic downturns (IADB, 2006 and IMF, 2007).

Reducing the volatility of expenditures could also enhance their efficiency. The stop-andgo nature of capital expenditures may be contributing to the inefficiency of these outlays. In a similar vein, more stable and predictable growth of outlays in the social sectors would facilitate progress in implementing health and education programs. 


\section{Appendix I. Econometric Methodology Used to Assess the CYCLICALITY OF SPENDING}

Table 1 reports on the country estimates on the short-run elasticity of spending with respect to output from Akitoby and others (2006). These authors estimate the following errorcorrection model to assess the relationship between central government spending on category $i\left(G_{i}\right)$ and real output $(Y)$ for a given country:

$$
\Delta \log G_{i t}=\mu+\beta_{0} \Delta \log Y_{t}+\gamma\left[\log G_{i, t-1}-\delta \log Y_{t-1}\right]+\varepsilon_{t}
$$

where $\beta_{0} \Delta \log Y_{t}$ captures the impact of changes in output on spending in the short-run. The coefficient $\beta_{0}$ measures the short-run elasticity of government spending with respect to output. These coefficients, estimated separately for different categories of expenditure $(G)$, are reported in Table 1.

The second term, $\gamma\left[\log G_{i, t-1}-\delta \log Y_{t-1}\right]$, measures an error-correction term and the movement of spending back to its long-run equilibrium. In this term, $\delta$ indicates the long-run elasticity of government spending with respect to output, and $\gamma$ (if negative) is the rate at which government spending adjusts to past disequilibrium.

Estimates for Table 2 follow a modified version of IMF (2007) and Balassone and Francese (2004). To estimate the impact of changes in the output gap on government expenditure $(\varepsilon)$, a regression is estimated for the following equation:

$g_{t}=\alpha_{0}+\beta_{1} g_{t-1}+\beta_{2} C_{t}+\beta_{3} d_{t-1}+\varepsilon O_{t}+v_{t}$

where $g$ is the ratio of primary expenditures to GDP; $c$ is the log of the terms of trade; $d$ is the public debt-to-GDP ratio; and $o$ is the output gap ((actual GDP-potential GDP)/potential GDP)*100. This specification is fairly standard in the literature, although not all authors have included a variable to capture terms of trade effects, and most studies have focused on total (rather than primary) spending.

To test for the asymmetric reaction of government spending to positive and negative output gaps, the estimating equation is modified to

$g_{t}=\alpha_{0}+\beta_{1} g_{t-1}+\beta_{2} C_{t}+\beta_{3} d_{t-1}+\varepsilon_{P} O_{t}^{P}+\varepsilon_{N} O_{t}^{N}+v_{t}$

where $\varepsilon_{P} \neq \varepsilon_{N}$ and the suffixes $P$ and $N$ indicate whether the coefficient applies to positive $\left(o_{t}^{P}\right)$ or negative $\left(o_{t}^{N}\right)$ output gaps. When the observation for the output gap is positive, for example, $o_{t}{ }^{P}$ equals the observed value of the output gap; when the output gap is negative, $o_{t}^{P}$ is zero. 


\section{Appendix II. The EfFiciency of Public InVestment in Latin America}

\section{A. Methodology}

Following the approach used in a number of studies (e.g., Gupta and Verhoeven, 2001; Clements, 2002; Herrera and Pang, 2005), the efficiency of public spending can be assessed by relating public outputs to the spending that was allocated to achieve them. In the present context, this is done by evaluating the relationship between public investment and infrastructure outputs.

Using a nonparametric technique (Free Disposable Hull Analysis, or FDH), a production function linking spending inputs and infrastructure outputs is estimated. FDH efficiency analysis first identifies efficient countries, that is, those countries that produce more outputs compared to other countries that spend as much or more. Those countries are assigned an efficiency score of 1 . Then, for the countries that are less efficient, an efficiency score is derived by taking the ratio of spending of the efficient country (E) and spending of the less efficient country (A), that is $\varepsilon_{\text {input }}(\mathrm{A})=$ spending(E)/spending(A) (this is the input efficiency score of the less efficient country - the output efficiency score is given by output in country A over that of country E). This efficiency score is, by construction, less than 1 . The input efficiency score can be interpreted as the minimum level of spending that other countries have needed to achieve the same or a higher level of infrastructure outputs, expressed as a share of actual investment spending. In the narrow interpretation of efficiency outlined below, this implies that the maximum savings from efficiency enhancement are 1 minus the input efficiency score.

FDH provides a powerful tool for ranking countries by level of efficiency, but caution is needed in interpreting the results. FDH provides several advantages: it is not an econometric exercise and does not require imposing specific functional forms on the efficient frontier. However, FDH does assume that the chosen input and output variable are related through a production process. Narrowly interpreted, FDH measures technical efficiency—but this assumes that the right inputs and outputs have been identified, and that countries all have access to the same production technology. Less narrowly interpreted, FDH provides an assessment of how countries compare in how much they spend and the policy objectives they pursue with this spending. Apart from technical inefficiency, there can be a wide variety of reasons for why efficiency varies, including varying production technologies, differences in policy objectives, and the impact of unidentified inputs and exogenous factors (for example, geography would impact the efficiency of spending on roads, as a mountainous country would spend more per kilometer while still operating at maximum technical efficiency). In addition, the efficiency scores from FDH analysis are highly sensitive to country sample selection and measurement error. Finally, in the present context, some caution is required in interpreting the rankings as a yardstick of the current degree of efficiency in spending, 
given that the exercise is largely based on data through 2001, the most recent available on a disaggregated, cross-country basis.

A particular issue in the case of infrastructure spending in Latin America is that the private sector undertakes a sizeable share of infrastructure investment (see Appendix Table 1 below). As such, it is not possible to strictly relate public spending and output indicators. A second best alternative-adopted for this study —is to assess the relationship between total spending (including by the private sector) and outputs. In addition, an adjusted measure is computed, based on a correction for the impact of private sector participation on the efficiency rankings. ${ }^{29}$

\section{B. Data}

The efficiency analysis is carried out on data for the 1990s and early 2000s for a set of seven Latin American countries (Argentina, Bolivia, Brazil, Chile, Colombia, Mexico, and Peru) and five infrastructure sectors (rails, roads, electricity, water, and telecommunications). Data on public and private infrastructure spending by sector comes from Calderón and Servén (2004), with updates also provided by Luis Andres of the World Bank (Appendix Table 1).

Appendix Table 1. Infrastructure Spending in Latin America, 1991-2001

(Average, in percent of GDP) $1 /$

\begin{tabular}{llll}
\hline Country & Total & Public & Private \\
\hline Argentina & 1.5 & 0.4 & 1.2 \\
Bolivia & 7.4 & 3.2 & 4.2 \\
Brazil & 2.4 & 1.3 & 1.1 \\
Chile & 4.6 & 1.6 & 3.0 \\
Colombia & 5.0 & 3.5 & 1.5 \\
Mexico & 1.7 & 0.6 & 1.1 \\
Peru & 1.7 & 0.6 & 1.1 \\
\hline
\end{tabular}

1/ Includes spending on rail, roads, electricity, water, and telecommunications.

The change in the stock of infrastructure is based on the World Bank's World Development Indicators database. Appendix Table 2 presents annual percentage improvements in infrastructure outcomes. The figures indicate that improvements in infrastructure have varied

\footnotetext{
29 This is done in two steps: first, running a truncated regression assessing the relationship between efficiency and the private sector share across all countries; second, estimating the corrected efficiency score for the sector on the basis of this regression and the share of the private sector in that country relative to other countries. This implies a downward adjustment on the efficiency scores for countries with a high level of private sector participation.
} 
widely by country and sector, with the most noteworthy gains in road, electricity, and telephones achieved by Chile. The results also suggest that countries with relatively high levels of spending (e.g., Bolivia and Colombia) have not achieved the most rapid progress.

Appendix Table 2. Infrastructure Improvements, 1990s and Early 2000s

(Average annual change, in percent)

\begin{tabular}{|c|c|c|c|c|c|c|c|c|}
\hline Country & $\begin{array}{l}\text { Rail lines } \\
\text { (km/1000 } \\
\text { capita) }\end{array}$ & $\begin{array}{l}\text { Roads } \\
\text { (meters/ } \\
\text { capita) }\end{array}$ & $\begin{array}{l}\text { Paved } \\
\text { roads } \\
\text { (meters/ } \\
\text { capita) }\end{array}$ & $\begin{array}{l}\text { Electricity } \\
\text { losses } \\
\text { (\% of total } \\
\text { output) 1/ }\end{array}$ & $\begin{array}{l}\text { Electricity } \\
\text { access by } \\
\text { households } \\
\text { (\% of total } \\
\text { pop) }\end{array}$ & $\begin{array}{l}\text { Electric } \\
\text { power } \\
\text { cons. } \\
\text { (kWh per } \\
\text { capita) }\end{array}$ & $\begin{array}{l}\text { Water } \\
\text { access } \\
\text { (\% of total } \\
\text { pop) }\end{array}$ & $\begin{array}{l}\text { Main } \\
\text { telephone } \\
\text { lines } \\
\text { (per } 1000 \\
\text { workers) }\end{array}$ \\
\hline & $1990-2002$ & 1992-1999 & 1992-1999 & $1991-2002$ & Latest 2/ & $\begin{array}{l}\text { Early 90s - } \\
\text { Early 00s } \\
3 /\end{array}$ & 1990-2002 & 1991-2002 \\
\hline Argentina & -0.76 & -1.18 & -0.77 & -0.81 & ... & 5.77 & $\ldots$ & 10.55 \\
\hline Bolivia & -1.92 & -0.10 & 7.33 & -0.66 & 2.77 & 4.83 & 1.50 & 11.64 \\
\hline Brazil & -0.48 & -0.92 & -5.58 & 0.79 & 6.29 & 2.61 & 0.60 & 20.63 \\
\hline Chile & -6.28 & -1.53 & 3.18 & -4.26 & $\ldots$ & 10.21 & 0.46 & 16.30 \\
\hline Colombia & 0.01 & -1.08 & 1.69 & -0.71 & 0.59 & 0.04 & 0.00 & 12.88 \\
\hline Mexico & 0.68 & 2.98 & 1.66 & 1.32 & $\ldots$ & 4.85 & 1.15 & 9.91 \\
\hline Peru & 0.59 & 0.39 & 4.29 & -0.47 & -0.14 & 4.19 & 0.79 & 14.03 \\
\hline
\end{tabular}

1/A decline in efficiency losses implies an improvement in the efficiency of electricity distribution.

2/ The improvement is calculated based on the difference between the last year available in the 1990s and the earliest year available in the 1990s.

3/ Improvement in average use 1991-1993 to 1999-2002.

\section{Results}

Appendix Table 3 presents the results of the FDH analysis. The results are based on an aggregation of the efficiency scores matching spending and outputs in rails, roads, electricity, water, and telecommunications. Each sector was weighted by its share in public sector investment spending. The results reveal a large amount of inefficiency, given the significant difference from the efficiency frontier (an efficiency score of 1.0) in many countries. Inefficiencies are especially noteworthy in Bolivia and Colombia, while Chile and Mexico are among the most efficient countries. ${ }^{30}$ In the case of Chile, the high level of efficiency owes to its substantial progress in improving infrastructure indicators, while in the case of Mexico, high efficiency is attributable to continued progress of output indicators in conjunction with low levels of expenditures. The adjustment of the efficiency scores for differing levels of private sector participation has little effect on the country rankings.

\footnotetext{
${ }^{30}$ The results for Colombia, however, should be interpreted with caution for a number of reasons (see main text for further discussion).
} 
Appendix Table 3. Aggregated Public Efficiency Scores

\begin{tabular}{lllllll}
\hline Country & $\begin{array}{l}\text { Public } \\
\text { Efficiency 1/ }\end{array}$ & Rank & $\begin{array}{l}\text { Level of Public } \\
\text { Efficiency }\end{array}$ & $\begin{array}{l}\text { Adjusted Public } \\
\text { Efficiency 2/ }\end{array}$ & $\begin{array}{l}\text { Adjusted } \\
\text { Rank }\end{array}$ & $\begin{array}{l}\text { Adjusted Level of } \\
\text { Public Efficiency }\end{array}$ \\
\hline Mexico & 0.974 & 1 & High & 0.824 & 1 & High \\
Argentina & 0.804 & 2 & High & 0.530 & 4 & Medium \\
Chile & 0.802 & 3 & High & 0.732 & 2 & High \\
Peru & 0.655 & 4 & Medium & 0.598 & 3 & Medium \\
Brazil & 0.410 & 5 & Medium & 0.432 & 5 & Medium \\
Bolivia & 0.218 & 6 & Low & 0.036 & 7 & Low \\
Colombia & 0.202 & 7 & Low & 0.253 & 6 & Low \\
\hline
\end{tabular}

1/ Efficiency in each sector aggregated using the share of public investment in each applicable sector.

2/ Adjusted by the effect of private sector spending on the efficiency score in each sector. 


\section{REFERENCES}

Akitoby, Bernardin, Benedict Clements, Sanjeev Gupta, and Gabriela Inchauste, 2006, "Public Spending, Voracity, and Wagner's Law in Developing Countries," European Journal of Political Economy, Vol. 22, pp. 908-924.

Alesina, Alberto, and Guido Tabellini, 2005, “Why Is Fiscal Policy So Often Procyclical?” NBER Working Paper No. 11600 (Cambridge, Massachusetts National Bureau of Economic Research).

Alier, Max, 2007, “Measuring Budget Rigidities in Latin America,” IMF Working Paper, forthcoming (Washington: International Monetary Fund).

Balassone, Fabrizio, and Maura Francese, 2004, “Cyclical Asymmetry in Fiscal Policy, Debt Accumulation, and the Treaty of Maastricht,” Temi di Discussione No. 531, December (Rome: Banca d’Italia).

Calderón, César, and Luis Servén, 2004, “Trends in Infrastructure in Latin America,” World Bank Policy Research Paper No. 3401 (Washington: World Bank).

Centro de Políticas Sociais, Fundação Getulio Vargas, 2006, "Poverty, Inequality, and Stability: The Second Real.” Available on the Internet at http://www.fgv.br/cps/pesquisas/site ret eng/.

Chu, Ke-young, Hamid Davoodi, and Sanjeev Gupta, 2000, "Income Distribution and Tax, and Government Social Spending Policies in Developing Countries,” WIDER Working Paper No. 214.

Clements, Benedict, 2002, “How Efficient is Education Spending in Europe?” European Review of Economics and Finance, Vol. 1, pp. 3-26

Clements, Benedict, Sanjeev Gupta, and Gabriela Inchauste, 2004, "Fiscal Policy for Development: An Overview,” in S. Gupta, B. Clements, and G. Inchauste, eds., Helping Countries Develop: The Role of Fiscal Policy (Washington: International Monetary Fund).

Davoodi, Hamid, Erwin Tiongson, and Sawitree Asawanuchit, 2003, "How Useful Are Benefit Incidence Analyses of Public Education and Health Spending?” IMF Working Paper 03/227 (Washington: International Monetary Fund).

Debrun, Xavier, and Manmohan Kumar, 2006, “The Discipline-Enhancing Role of Fiscal Institutions: Theory and Empirical Evidence,” paper presented at the European Commission Directorate General for Economic and Financial Affairs Workshop, 
“The Role of Fiscal Rules and Institutions in Shaping Budgetary Outcomes,” Brussels, November.

De Ferranti, David, Guillermo Perry, Indermit Gill, J. Luis Guasch, William Maloney, Carolina Sánchez-Páramo, and Norbert Schady, 2003, Closing the Gap in Education and Technology (Washington: World Bank).

De Ferranti, David, Guillermo Perry, Francisco Ferreira, and Michael Walton, 2004, Inequality in Latin America: Breaking with History? (Washington: World Bank).

Echebarría, Koldo, and Juan Cortázar, 2006, "Public Administration and Public Employment Reform in Latin America,” in Eduardo Lora, ed., The State of State Reform in Latin America (Washington: Inter-American Development Bank).

Economic Commission on Latin America and the Caribbean (ECLAC), 2006a, Social Panorama of the Americas (Santiago: United Nations). , 2006b, Shaping the Future of Social Protection: Access, Financing, and Solidarity (Santiago: United Nations).

Fay, Marianne, and Mary Morrison, 2005, Infrastructure in Latin America and the Caribbean: Recent Developments and Key Challenges (Washington: World Bank).

Filc, Gabriel, and Carlos Scartascini, 2006, “Budgetary Institutions,” in Eduardo Lora, ed., The State of State Reform in Latin America (Washington: Inter-American Development Bank).

Gavin, Michael, and Roberto Perotti, 1997, “Fiscal Policy in Latin America,” NBER Macroeconomic Annual1997 No. 12, pp. 11-71 (Cambridge, Massachusetts: MIT Press).

Gill, Indermit, Truman Packard, and Juan Yermo, 2005, Keeping the Promise of Social Security in Latin America (Washington: World Bank).

Gupta, Sanjeev and Marijn Verhoeven, 2001, “The Efficiency of Government Expenditure: Experiences from Africa,” Journal of Policy Modeling, Vol. 23, pp. 433-467.

Hammouya, Messaoud, 1999, Statistics on Public Sector Employment, Methodology, Structure and Trends (Geneva: International Labor Office).

Herrera, Santiago, and Gaobo Pang, 2005, "Efficiency of Public Spending in Developing Countries: An Efficiency Frontier Approach,” World Bank Policy Research Working Paper No. 3645 (Washington: World Bank).

Inter-American Development Bank (IADB), 2005, The Politics of Policies (Washington). 
, 2006, Living With Debt: How to Limit the Risks of Sovereign Debt (Washington).

International Monetary Fund, 2003, World Economic Outlook September 2003: Public Debt in Emerging Markets (Washington).

, 2005, "Public Investment and Fiscal Policy_Lessons from the Pilot Country Studies" Available on the internet at www.imf.org (Washington).

, 2006a, Public-Private Partnerships, Government Guarantees, and Fiscal Risk, prepared by a staff team led by Richard Hemming (Washington).

, 2006b, Regional Economic Outlook: Western Hemisphere, November (Washington).

, 2007, Promoting Fiscal Discipline, Occasional Paper prepared by the Fiscal Affairs Department, forthcoming (Washington).

Kaminsky, Graciela L., Carmen Reinhart, and Carlos Végh, 2004, "When it Rains, it Pours: Procyclical Capital Flows and Macroeconomic Policies," NBER Working Paper No. 10780 (Cambridge, Massachusetts: National Bureau of Economic Research).

Kaufmann, Daniel, Aart Kraay, and Massimo Mastruzzi, 2006, “Governance Matters V: Governance Indicators for 1996-2005” (Washington: World Bank).

Lindert, Kathy, Emmanuel Skoufias, and Joseph Shapiro, 2006, Redistributing Income to the Poor and the Rich: Public Transfers in Latin America and the Caribbean (Washington: World Bank).

Lopez-Claros, Augusto, Michael E. Porter, Xavier Sala-i-Martin, and Klaus Schwab, 2006, The Global Competitiveness Report 2006-2007: Creating an Improved Business Environment (Geneva: World Economic Forum).

Mullis, I.V.S., M.O. Martin, E.J. Gonzalez, and S.J. Chrostowski, 2004a, TIMSS 2003 International Mathematics Report (Chestnut Hill, MA: TIMSS \& PIRLS International Study Center, Lynch School of Education, Boston College). , 2004b, TIMSS 2003 International Science Report (Chestnut Hill, MA: TIMSS \& PIRLS International Study Center, Lynch School of Education, Boston College).

Organisation for Economic Co-operation and Development (OECD), 2001, Highlights of Public Sector Pay and Employment Trends (Paris). , 2004, Learning for Tomorrow's World: First Results from PISA 2003 (Paris). Roldos, Jorge, 2006, “Pension Reform and Macroeconomic Stability,” mimeographed. 
Sahay, Ratna, and Rishi Goyal, 2006, "Volatility and Growth in Latin America: An Episodic Approach,” IMF Working Paper 06/287 (Washington: International Monetary Fund).

Singh, Anoop, and Martin Cerisola, 2006, "Sustaining Latin America’s Resurgence: Some Historical Perspectives,” IMF Working Paper 06/252 (Washington: International Monetary Fund).

Schiavo-Campo, Salvatore, Giulio de Tommaso, and Amitabha Mukherjee, 1997, “An International Statistical Survey of Government Employment and Wages,” Policy Research Working Paper No. 1806 (Washington: World Bank).

Stein, Ernesto, Ernesto Talvi, and Alejandro Grisanti, 1998, "Institutional Arrangements and Fiscal Performance: The Latin American Experience,” IADB Working Paper No. 367 (Washington: Inter-American Development Bank).

Talvi, Ernesto, and Carlos Végh, 2005, "Tax Base Variability and Procyclical Fiscal Policy," Journal of Development Economics, Vol. 78, October, pp. 156-190. 